\title{
Malagasy Phonological History and Bantu Influence
}

\author{
Alexander Adelaar \\ NATIONAL MUSEUM OF ETHNOLOGY, OSAKA, \\ AND UNIVERSITY OF MELBOURNE
}

In this paper I give a critical assessment of John Wolff's interpretation of the
phonological history of Malagasy as it appears in his recent book on Proto-
Austronesian phonology. The various aspects of Wolff's approach that I deal
with include the development of final open syllables, the spirantization and
fricativization of stops and semivowels, the reduction of *-nk- clusters, and
Wolff's interpretation of the development of Proto-Austronesian *s (or *c in
Wolff's notation). I also discuss the impact of Bantu languages on the develop-
ment of Malagasy after the migration of its speakers to East Africa. This impact
was a major one, although it is seriously underestimated in Wolff's perspective.

1. INTRODUCTION. ${ }^{1}$ In this paper I give a critical assessment of John Wolff's interpretation of the phonological history of Malagasy (MLG) as it appears in his ProtoAustronesian (PAN) phonology (Wolff 2010). ${ }^{2}$ I also discuss the impact of Bantu languages on the development of MLG after the migration of its speakers to East Africa. This impact was a major one, although it is seriously underestimated in Wolff's perspective.

Wolff recently published this monumental two-volume work in an endeavor to improve the phonology and the many etyma that Otto Dempwolff(1934-38) and subsequent Austronesianists had made in the process of reconstructing Proto-MalayoPolynesian (PMP) and PAN. It is based on a generally thorough analysis of the phonologies of the languages forming the basis of his study. For some of these languages, he unquestionably gives a better insight into their histories and phonological developments than had been done before him. In the case of MLG, however, it appears that his approach is very much dictated by generalizations and intuitive explanations that are on the whole unfortunate, if not just plain incorrect.

1. I wrote this paper in the summer of 2011 at the National Museum of Ethnology in Osaka. I would like to thank the Museum, and in particular my host, Prof. Ritsuko Kikusawa, for their hospitality and good care. I am also greatly indebted to Roger Blench (Cambridge, UK), Ritsuko Kikusawa (Osaka), John Hajek (Melbourne), Laurent Sagart (Paris), and particularly Waruno Mahdi (Berlin) and Laurie Reid (Osaka), for their critical reading of earlier drafts of this paper. The usual disclaimers apply.

2. For further details on abbreviations of language names, data sources, orthography, and so on, see the appendix. 
In the analysis of a large corpus of multi-interpretable lexical and phonological data, occasional small errors of judgment are, of course, almost impossible to avoid and, if they occur, they will not necessarily invalidate one's research results in their main outline. In the study under investigation, however, there is cause for more serious concern because the number of errors has reached a critical mass, and the situation is exacerbated by the author's failure to make proper use of previous works on MLG phonological history that have been published since Dempwolff(1937). ${ }^{3}$

The linguistic history of MLG has been the topic of various major publications, including Dahl (1951), Hudson (1967), Dahl (1977), Mahdi (1988), Simon (1988), and many articles by the present author (including Adelaar 1989, 1995a,b, 2009a, 2009b, 2010). Malagasy was also one of the languages on which Dempwolff built his PMP comparative phonology. While much remains to be done, it is undoubtedly one of the most thoroughly investigated Austronesian languages, not only historically, but also synchronically. Its morphophonemic structure is also among the more complicated Austronesian ones, exhibiting, among other features, suppletion, a different structure of the word and root, paragogic vowels, final consonant deletion in compounds, sandhi rules that differ according to the nature of a phrase, and unpredictable and shifting stress.

Wolff does refer to some of the authors mentioned above, but the way he generally ignores them in his analysis leaves the impression that he only read their publications in a cursory way at best. By making very detailed and careful phonological analyses in which they also used comparative data from Southeast Barito (SEB) languages ${ }^{4}$ and MLG regional dialects, these authors together laid the groundwork for a chronologically staged language reconstruction. Making use of it would have allowed Wolff to be much more detailed and precise than is usually possible in the reconstruction of Austronesian languages. In fact, he missed a golden opportunity to demonstrate such a laboratory case, limiting himself to a treatment of the immediate relation between PAN and Merina (MRN).

A clear demonstration of this shallow approach is Wolff's treatment of root-final consonants. It is a well-known fact that, in MRN, historical final consonants merged as $-t r,-k$, or $-n$ (each followed by a paragogic voiceless or "whispered" vowel $\breve{a}$ ) or became $\emptyset$. However, before a vowel-initial suffix, these merged consonants or $\emptyset$ sometimes alternate with other consonants, some of which reflect more faithfully the original PMP/PAN final consonants, while other consonants do not. Wolff (2010:452) simply informs the reader that all MRN final consonants have merged in -tră, $-k \breve{a}$, or -năa, or were lost, and that reflexes of the original final consonants sometimes emerge at morpheme boundaries before vowel-initial suffixes. As a general instance, he gives the word inună 'to drink' $(<$ *PAN *inum 'to drink'), in which final *m reappears when the undergoer suffix is

3. Too much reliance on one's own intuition is also a more general problem in Wolff's writing style. A telling example is footnote 6 on p.451, in which he ascribes the use of $o$ for the MLG high back rounded vowel $(u)$ to French influence. While this use hardly applies to French orthography, modern Malagasy spelling was designed by the London Missionary Society in 1823 (long before Madagascar became a French colony). This is well documented, and is mentioned in, among others, Richardson (1885:5), Dahl (1951:7-8), and, more recently, Steinhauer (2005:79).

4. These are the Austronesian languages with which MLG is directly subgrouped (Dahl 1951, 1977, Hudson 1967). They are spoken along the eastern shores of the Barito River in Central Kalimantan Province, and in a few disconnected areas in South Kalimantan, Indonesian Borneo. 
attached to it: inùm-ină. But in fact, the rule determining which consonant appears before suffixes is much less random. A whole line of linguists has looked into the issue, from van der Tuuk (1865) onwards, and the issue found its most comprehensive treatment in Mahdi (1988), allegedly one of Wolff's main sources. Mahdi (1988:241-62) shows that the nature of these consonants is determined by a complex combination of phonotactic and historical factors. ${ }^{5}$

Wolff's ignorance of the existing literature is not limited to Malagasy linguistics but also concerns recent interdisciplinary work dealing with the settlement history of Madagascar (see section 7).

In my evaluation, I will not be commenting on the PAN phonological system and etymologies proposed by Wolff, as this has already been done by others (Blust 2011, Mahdi forthcoming). I will only allow myself to make a few brief comments. Wolff's identification of Dempwolff's *g' and *g as one and the same protophoneme has very little explanatory value from the perspective of MLG phonological history, yielding the unlikely combination of reflexes of $h$ in initial position, $r$ intervocalically, and -tră in word-final position. Furthermore, Wolff's ideal of a maximally balanced and harmonious PAN phonology is unnatural from a general phonological point of view, and it certainly does not find much support in MLG phonological history. Finally, in demonstrating how individual languages derive from his version of PAN phonology, Wolff has to make use of an alarming number of ad hoc explanations. Using the notion of "contamination" to explain some unexpected sound changes is putting a particularly heavy strain on the principle of regular sound correspondences.

In the following sections, I will deal with various aspects of Wolff's approach. They include the development of final open syllables (section 2), the spirantization and fricativization of stops and semivowels (section 3), the origins of the retroflex affricate $t r$ (section 4), the reduction of *-nk- clusters (section 5), and Wolff's interpretation of the development of PAN *s (or *c in Wolff's notation) (section 6). I address Bantu contact influence in section 7. Wolff does not consider this influence a major factor in the phonological history of MLG. He makes this explicit in a section specifically dealing with "Bantu influence on Malagasy" (2010:464-66), but it also appears in his treatment of various phonological phenomena, including most of those dealt with in the various sections of this paper. I assess some of Wolff's MLG etymologies in section 8 and end with concluding remarks in section 9 .

\section{THE DEVELOPMENT OF MALAGASY FINAL OPEN SYLLABLES.}

Wolff does not believe that Bantu influence had much to do with the development of MLG vocalic endings. According to him, such endings developed independently in many

5. For instance, -tră usually becomes - $r$ - before a suffix, as in lavitră 'far' vs. ha-lavir-ană 'distance, remoteness'. However, it may become - $t$ - if descending from a historical *t, as in uzatră 'muscle' vs. uzat-ină 'muscular' (cf. PAN * $\mathrm{uRaC}$ 'tendon, muscle'), and it becomes - $t$ - as a rule at the end of a root that already has an -r- in it, as in haratră 'shaving', fi-haratră 'a razor', harat-ană 'to be shaved'. There are also a few words in which -tră alternates with $-f$ $\left(<*\right.$-b, ${ }^{*}$-p), as well as other irregular cases; see 2.1. Comparable factors play a role in the appearance of final consonants before a suffix after $-k \breve{a}$, -năa, and (in case a final consonant has disappeared) $-\varnothing$, although the exact rules vary in each instance and have become rather weak in the case of $-n a \breve{~}$. 
of the world's languages, including languages in eastern Indonesia and Oceania. While that may be the case, it does not explain much in relation to MLG. The latter did not originate in eastern Indonesia or Oceania but in Borneo, a vast island with an enormous variety of languages, none of which has developed vocalic endings. One also recalls that MLG, the only SEB language that does have such endings, has been spoken for at least thirteen hundred years in the East African coastal region, where the neighboring languages do have vocalic endings. These languages are Kiswahili and the Comorian languages (Shingazidja, Shimaore, Shimwali, and Shindzuani), which all belong to the Sabaki branch of North East Coast Bantu. Given such a specific historical and geographic context, Wolff's arguments against Bantu influence on the development of vocalic endings are not as straightforward as they may seem from a sheer typological perspective.

2.1 WOLFF'S ANALYSIS. According to Wolff, the process leading to the development of vocalic endings was set in motion as a result of word stress moving away from final syllables in those cases where it was on the final syllable. This was followed by final consonant attrition, which happened in two stages. In stage I, final nasals and final *1 merged as [n], *d and $*_{t}$ merged as [t], labials merged with *k (presumably to [k]), and $*_{h}$, ${ }^{q}$, and ${ }^{*}$ s were lost entirely. In stage II, the resulting final consonants were lost entirely, leaving a word structure with open final syllables. Stage I happened in all MLG dialects; stage II happened in only some of the dialects, including the precursor of the MRN dialect on which standard MLG is based. After stages I and II, the dialects that did retain final consonants influenced those that had lost them, such that the latter reintroduced final consonants. They also added paragogic vowels in order to maintain an open final syllable structure.

This scenario is a radical departure from previous analyses. It is also unnecessarily complicated, and there is very little evidence to support it. Why hypothesize a historical stage in which all consonants in word-final position have "gone walkabout" if today there is no MLG dialect testifying to such a state of affairs? And why postulate an unspecified source dialect from which final consonants were reintroduced into MRN (and apparently in other dialects that supposedly lost all final consonants)? This is an enormous speculative detour, instead of simply assuming that the MLG dialects never lost all their original final consonants. Wolff's reason is that in this way he can explain the alleged occurrence of (i) words that failed to reintroduce these final consonants, (ii) doublet words, one of which reintroduced a final consonant (+ paragogic vowel) whereas the other never did, and (iii) words with an unexpected final consonant as a result of speakers' incorrect reanalysis. In general, such irregularities often occur if certain phonological features were originally lost and then reintroduced via a conservative dialect. But in the present case, they are perceived irregularities mainly based on a wrong assessment of the overall phonological history of MLG.

Final consonant loss in MLG is much more contained and regular than appears from Wolff's analysis. It only concerns final nasals, not *-t or *-k. There is a tendency to lose final nasals in all MLG dialects. Some dialects have lost all final nasals, others have lost final nasals in some words but not in others. Merina is probably least affected, although it occasionally also lost final nasals; the ones it retained have merged as -nă. This tendency 
to lose final nasals explains Wolff's instance of *ipən > ify 'tooth', and the occurrence of doublets with and without final nasal in *bankuwan > vakùa, vakùană 'Pandanus sp.'. It does not apply to Wolff's third instance, *dahum > rànu 'water', simply because the final nasal loss here had already occurred at the Proto-SEB stage: Maanyan (MNY) and other SEB languages have ranu or ranu' (Hudson 1967, Dahl 1977, Mahdi 1988). The pattern of final nasal loss is shown in ${ }^{6}$

According to Wolff(2010:452), "the Sakalava dialect' ${ }^{7}$ of western Madagascar shows reflexes of a large number of forms ending in PAN stop consonants that never developed

\section{TABLE 1. FINAL NASALS IN MALAGASY DIALECTS}

\begin{tabular}{|c|c|c|c|c|c|c|c|}
\hline English & PMlg & MNY & MRN & SSK & NSK & Old Taimoro & Old SBM \\
\hline path & *lalan & lalan & làlană & làla & làlayă & $1<$ um $>$ alan $(113)$ & lalan \\
\hline name & *ayaran & yaran & anàrană & ayàra & ayàrayă & & anare \\
\hline person & *ulun & ulun & ùlună & ùlu & ùlu & ulun (113) & oulon \\
\hline itchy & *katen & katen & hàtină & hàte & - & & hate \\
\hline leaf & *rawen & rawen & ràvină & ràve & ràvin & & rave \\
\hline moon, month & *wulan & wulan & vùlană & vùla & - & & voulan \\
\hline word & $\begin{array}{l}(<\text { JAV } \\
\text { wulay })\end{array}$ & - & vùlană & vùla & - & & voulanh \\
\hline molar & *wayan & - & vàzană & vàza & vàzayă & wayay (88) & vazan \\
\hline forehead & *handriy & - & hàndrină & hàndri & - & handrin (87) & $\begin{array}{l}\text { hanrihi, } \\
\text { hânri }\end{array}$ \\
\hline nose & *urun & uruy & ùrună & ùru & ùruy & uruy (88) & oron \\
\hline $\begin{array}{l}\text { bird }(<\text { MAL } \\
\text { burun })\end{array}$ & *wuruy & wurun & vùrună & vùru & vùruy & wuruyu* & vourou \\
\hline neck & *wuyuy & $-^{\dagger}$ & vùzună & vùzu & vùzuy & wuyun (88) & vouzonh \\
\hline $\begin{array}{l}\text { having } \\
\text { vertigo }\end{array}$ & $\begin{array}{l}\text { (BJRMAL } \\
\text { panin) }\end{array}$ & - & fànină & fàny & - & fanin $(92)^{*}$ & - \\
\hline wall & *rindrin & - & rìndrinaă & rìndri & - & & ririn-bato \\
\hline inhabit & *uney & uney & ùnină & - & & f/uney $(72)^{* *}$ & monengh \\
\hline breath, life & *ahen & ahen $^{\dagger \dagger}$ & àina & ài & & ain (93) & ainh \\
\hline black & $*$ inte $[\mathrm{m}]$ & intem & ma-ìnti & ma-ìnte & & ma-inti (77) & mainthi \\
\hline $\operatorname{six}$ & *enem & enem & ènină (-m-) & ène & & & enem \\
\hline night & *alem & alem & àlină & àle & & hale, halen & halem \\
\hline alive & *welum & welum & vèlună (-m-) & vèlu (-m-) & & welun (45) & vellom \\
\hline drink & *inu $[\mathrm{m}]$ & $\mathrm{m} / \mathrm{inu}$ & ìnună (-m-) & ìnu & & & minon \\
\hline deep & *lale [m] & lale & làlină & làle & & & lalen \\
\hline
\end{tabular}

* $\quad$ Found in Dahl (1983:36).

$\dagger \quad$ Among the East Barito languages, MNY, Samihim, Taboyan, Dusun Deyah, and Dusun Malang have diuy, and Lawangan has biuy, all meaning 'neck'. MLG vùzună agrees with Lawangan biun: the penultimate $u$ in MLG is the result of regressive assimilation from *i to

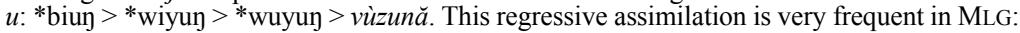
cf. *qijuSun 'nose' > ùrună; *tiduR 'sleep' > tùru; *qali-mukən 'pigeon'> MLG dumùhină; *talikuj 'back' > Old Taimoro talutuku (Ferrand 1906:91); *liuR 'moisture' > rù 'bouillon, broth'; MAL tumit 'heel' > tùmutra. In some cases, vowel metathesis applies instead, as in the following (Wolff 2010:458): *ikuR 'tail' > ùhi; *qatinu 'shadow' > ùnină 'shape or appearance of s.t.'; *tiduR > ma-tùri 'to sleep' (a variant form of tùru presented above).

\pm 'Having spells of vertigo'.

** 'State'; Ferrand also gives m/unin (114) 'to stay'.

$\dagger$ † 'Mind'.

6. Recall that language abbreviations may be found in the appendix. Relevant page numbers in Ferrand (1904) are added in parentheses after the Old Taimoro examples in tables 1 and 2.

7. More specifically SSK (see also the appendix). 
-nă, -trăa, and -kăa." Quite apart from the awkward formulation of this observation, ${ }^{8}$ it also misses the point that South Sakalava (SSK) is among the dialects that have lost all final nasals but have maintained $*_{\text {-t }}$ and ${ }^{*}$-k as a rule.

Another of Wolff's examples demonstrating the failure to reintroduce final consonants is *qatimatək > dimàty 'leech'. ${ }^{9}$ This form is recorded in Richardson's dictionary (1885), but it is a bit of a mystery and must be erroneous: all other MLG dictionaries listing a reflex of * qatimatək that I have been able to consult reflect * $k$. They include the following forms: MRN dimàtikă (Abinal and Malzac 1993), Bara MLG dimàtiki (Elli 1988), Antaisaka dimàtiki, Tanala dimàtiky (Beaujard 1998), Old SBM limateche, and Arabico-Malagasy (based on an ancient form of Taimoro MLG in Arabic script) dimàtiky (Dez 1982).

Three other alleged instances of the failure to reintroduce original final consonants are *ləpit 'fold' > dify' 'a fold, seam' (Wolff 2010:460), *lamək > lèmy 'supple, tender, weak' (2010:463), and *pənət 'plugged up' > feny 'enclosure, hedge' (2010:463). The form dify is not related to *lopit. Its meaning in Wolff (2010) is incorrect (Richardson has 'turning aside: a mode of plaiting the hair by dividing it on the forehead and carrying it behind the ears; a border plaited in mats, baskets, hats etc.'). In a footnote, Wolff also gives a second reflex lèfitră for *lopit, which is, of course, the correct one (one is left wondering how the occurrence of two supposedly regular reflexes for one etymon can be justified). The form lèmy can be dismissed on the grounds that it is not related to *lomək but is a regular reflex of either PMP *lemaq 'weak' (Dahl 1951:350) or PMP *ləməs 'soft' (Mahdi (1988:313, fn. 212). Dempwolff (writing *pənəd with final *d) already linked *pənət with MRN fèny, but Dahl (1951:66) proposed MRN fenitră, which is glossed in Richardson as 'four strips of rush placed at the bottom of a basket, etc., extending from corner to corner, and forming a foundation on which the basket is plaited'. This word is semantically much more in line with *penet than feny is.

Wolff's example of the reintroduction of a wrong final consonant is *tup, which in reduplicated form (*tup-tup) became the basis of mi-tùtutră 'be covered over' and its undergoer-oriented form tutùf-ană 'be covered'. It shows final -tră instead of expected - $k \breve{a}$. Here, Wolff depicts a very frequent development as if it were an irregular one. Dahl (1951:68-69) gave due attention to final *-b and *-p, showing that of all eleven MLG words reflecting a PMP etymon ending in a labial stop that he had been able to find, six ended in - $k a \breve{a n d}$ aive in -tră ; eight of these words still exhibit a labial $(-f-<*$ p) at morpheme boundaries. The eleven forms are as follows: ${ }^{10}$

(1) a. PMP *-b, *-p > MRN -kă:

*dilap 'to lick' > lèlakă (lelàf-ină)

*raprap 'to detach' > ràrakă (raràf-ană, raràh-ană) 'to be detached'

*lablab 'to dive, submerge' > lèlikă (lelèf-ană) 'covered'

*qadəp 'in front' > MRN àtrikă (atrèh-ană), SSK àtrekě (an-atrèf-a)

8. Obviously, the reference is to consonants in general rather than to stops only. The paragogic vowel in SSK is $-\breve{e}$, and the endings in question are consequently $(-\varnothing),-t s \breve{e}$, and $-k \breve{e}$.

9. Wolff spells the etymon involved alternately as *qałimatek (p. 452, p. 469) and *qałimateq (p. 458), which is particularly awkward, as *qatimatek and *qałimateq do feature as separate synonyms in his finderlist, each with its own MLG reflex (compare *qałimatek 'leech' > MLG dimàti(ka) 'leech' vs. *qałimateq 'leech' > MLG dinta 'leech').

10. The absence of a gloss after a form indicates that this form has the same meaning as the preceding one. 
*raqup 'to collect, bring together' > ràukă (raùf-ină)

*sisip 'to insert, stick into something' > sìsikă (sisih-ană, sisif-ană)

b. PMP *-b, *-p > MRN -tră:

*qudip 'to live' > Antaisaka MLG ùritry 'to breed, generate'

*səpsəp 'to suck' > sèsitră 'smoke hemp', sesèr-ină 'to be smoked'

*tuptup 'to cover' > tùtutră (tutùf-ană)

*unkab 'to open' > s/ùkatră (s/ukàf-ană)

Malay tankap 'to seize, grab' > tàkatră (takàr-ină) 'to reach'

These changes hardly fit the pattern of an occasional -tră introduced through wrong analysis in an otherwise regular process yielding $-k \breve{a}$. Dahl rightly describes them as an attempt by final labial stops to realign with the only two other final stops left.

To be fair to Wolff, I found three more words with historical final labial stops, two of which exhibit $-k \breve{a}$, and one -tră. They are:

(2) PAN *Seiup 'to blow'> MRN tsùkă, tsùf-ină (along with tsìukă 'breeze, wind', tsiùf-ină 'where the wind blows')

PMP *alap 'to take' > Betsileo MLG àlakă (Dahl 1951:328)

MAL rapkup 'hollow, cavity', mə-rankup 'cup hands together; cover, embrace' > MRN ràkutră 'a cover', rakùf-ană 'to be covered'

This brings the total number to 14: eight exhibiting $-k \breve{a}$, and six -trăa.

In a few cases, MLG dialects differ in the final consonant they exhibit. For instance, MRN lèlakă (lelàf-ină) 'to lick' (see above) has a corresponding lèlatră 'to suck' in Old Taimoro (Munthe 1982:92). Compare also the cognates of PMP *qaləb 'knee' in the following set: MNY ulu alep 'knee' (lit. 'head of knee'), PMLG *luka 'head' + *ale(t,k) > MRN luh/àlikă, Old Taimoro lu/halitri 'knee' (Ferrand 1904:92)

Other evidence against Wolff's analysis is that the substitution of a coronal consonant instead of a velar one for *-p also seems to have happened in some MNY etyma. Compare tabit 'doctor, medicine man'"l reflecting an earlier Malay tabip, (with Arabic tabib as its ultimate source; cf. Wehr 1994). The other is ngalat ( $<k$ /alat) 'to steal', with cognates alat in Bayan (Nanang, Kalamper, and Usman 1988:117) and hàlatră in MRN, which can be traced to PMP *alap ‘to take away' and *ka-alap ‘taken away'. This raises the possibility that the tendency to substitute a final coronal for *-p had already begun before the migration, casting doubt on the assumption that it was the side-effect of an alleged loss and reintroduction of final consonants in individual MLG dialects after the migration.

Finally, while the reflexes of *-b and *-p are distributed somewhat unpredictably over $-k \breve{a}$ and -tra, they never appear as -nă or $-\varnothing$. This is circumstantial evidence against Wolff's analysis: if - $k \check{a}$ were the only regular reflex of *-b and *-p, one would expect also to find - $n \breve{a}$ and $-\varnothing$ along with -tră as irregular reflexes due to wrong reanalysis; but this is not the case.

In summary, hardly any of Wolff's examples intended to demonstrate an erroneous reintroduction of final consonants bear scrutiny. There is basically no evidence in favor of his analysis, which must be rejected. 


\subsection{HOW DID OPEN FINAL SYLLABLES ACTUALLY DEVELOP IN}

MALAGASY? According to Wolff, open final sylables are typologically general enough to consider their occurrence in MLG as a spontaneous and independent development. However, a detailed account of the changes affecting final consonants from PAN to MRN shows that many of these never led to the development of an open final syllable structure: these are the ones that are also attested in the SEB languages of Central and South Kalimantan (Indonesian Borneo). The few changes that did contribute directly to the development of open final syllables are the monophthongization of diphthongs, and the addition of a paragogic vowel $\breve{a}$ to the three historical final consonants that were left in MRN. These changes happened after the migration, in a contact situation involving Sabaki languages, which all have final open syllables.

Premigratory changes may to some extent have paved the way for a final open syllable structure, but they were only incidental to the process, given that they never caused the development of a final open syllable structure in the SEB languages in Kalimantan.

The paragogic vowels that were added tend to differ in the various dialects: MRN has $-\breve{a}$, SSK $-\breve{e}$, Bara and Antaisaka $-\breve{l}$, and Taimoro has $-\breve{a}$ or $-\breve{-}$. (See table 2.) In NSK, the paragoge is assimilated to the vowel in the preceding syllable, although original final nasals are often not followed by any vowel. Old Taimoro also had echo vowels (Dahl 1983:67), although in the Old Taimoro texts this pattern is not always clear and may have been disturbed by the application of paragogic vowel rules pertaining to modern Taimoro. In some SBM lexical sources, paragogic vowels are not added at all. Various dialects do not add any vowel after a final nasal or have lost final nasals. This lack of uniformity shows that paragogic vowels are a very recent development.

The point could be made that the addition of a paragogic vowel in itself already suggests outside contact. Open final syllables are usually created through the attrition of final

\section{TABLE 2. COGNATE SETS EXEMPLIFYING PARAGOGIC VOWELS IN VARIOUS MALAGASY DIALECTS}

\begin{tabular}{|c|c|c|c|c|c|c|c|c|}
\hline $\begin{array}{l}\text { English } \\
\text { penis }\end{array}$ & $\begin{array}{l}\text { MRN } \\
\text { làtakă }\end{array}$ & $\begin{array}{l}\text { SSK } \\
\text { làtakĕ }\end{array}$ & $\begin{array}{l}\text { Bara } \\
\text { làtakî }\end{array}$ & $\begin{array}{l}\text { NSK } \\
\text { làtakă }\end{array}$ & $\begin{array}{l}\text { Old Taimoro } \\
\text { lataka (91) }\end{array}$ & $\begin{array}{l}\text { PMLG } \\
\text { *latak }\end{array}$ & $\begin{array}{l}\text { MNY } \\
\text { latak }\end{array}$ & $\begin{array}{l}\text { Old SBM } \\
\text { voalatache* }\end{array}$ \\
\hline ant & vìtsikă & vìtikĕ & $\begin{array}{l}\text { vìtikĭ, } \\
\text { vìtsikĭ }\end{array}$ & vìtsikĭ & - & $\begin{array}{l}\text { *witik/ } \\
\text { *witsik }\end{array}$ & wisik & vitsic \\
\hline neck & hàtukă & hàtukĕ & hàtukĭ & - & hatuku (89) & *hatuk & $\operatorname{katuk}^{\dagger}$ & hatocho \\
\hline nerve, tendon & ùzatră & ùzatsě & - & - & uyarri (87) & *uyat & uat & ozats \\
\hline navel & fùitră & fùetsĕ & fùitsı̌ & fùetrĭ & fuirri (91) & *pu(h)et & puhet & foetse \\
\hline afraid & tàhutră & tàhutse & tàhutsǐ & - & matahurru (115) & *tahut & takut & tahotse \\
\hline wind & rìvutră & rìvutsĕ & rìvutsĭ & rìvutrŭ & - & *riwut & riwut & rivoutse \\
\hline path & làlană & làla & làla & làlayă & 1<um>alan (113) & *lalan & lalan & lalan \\
\hline person & ùlună & ùlu & ùlu & ùlu & ulun (113) & *ulun & ulun & oulon \\
\hline molar & vàzana & vàza & vàza & vàzajă & wayay (88) & *wayay & - & vazay \\
\hline fore head & hàndrină & hàndri & hàndri & - & handriy (87) & *handrin & - & - \\
\hline to fly & sìdină & tìli & tìli & tìlinǐ & - & $\begin{array}{l}\text { *tilin, } \\
\text { *tsidin }\end{array}$ & silin & - \\
\hline nose & ùrună & ùru & ùru & ùruy & uruy (88) & *uruy & urun & oron \\
\hline bird & vùrună & vùru & vùru & vùruy & wuruju & *wuruy & wuruy & vourou \\
\hline
\end{tabular}

* Meaning 'testicle' and consisting of voa- 'fruit, product' + latache 'penis'.

$\dagger \quad$ 'To nod (in agreement)'. 
consonants or the addition of a paragogic vowel (sometimes a combination of both). Final consonant attrition must be a gradual process because it involves a loss of phonological information, which may cause a breakdown in communication. On the other hand, the addition of a paragogic vowel involves no such risk. Its application therefore better suits a language with closed final syllables trying to adapt typologically to languages with an open final syllable structure in a contact situation.

\subsection{AN ALTERNATIVE ACCOUNT OF THE HISTORY OF WORD-} FINAL CONSONANTS IN MALAGASY. In this section, I outline an alternative analysis of the history of MLG word-final consonants, distinguishing intermediate stages and making use of evidence from MNY, ${ }^{12}$ the MLG dialect variety, and early written forms of MLG. With this evidence, it is possible to reach a much more precise and chronologically qualified history of MLG final consonants. Changes are divided into three broad stages: PSEB, PMLG, and MLG. Those that took place at the PSEB stage are also attested in the SEB languages of Kalimantan and are premigratory; these are listed in table 3, and changes are labeled PSEB1, PSEB2, and so on.

\section{TABLE 3. RELEVANT CHANGES IN PSEB}

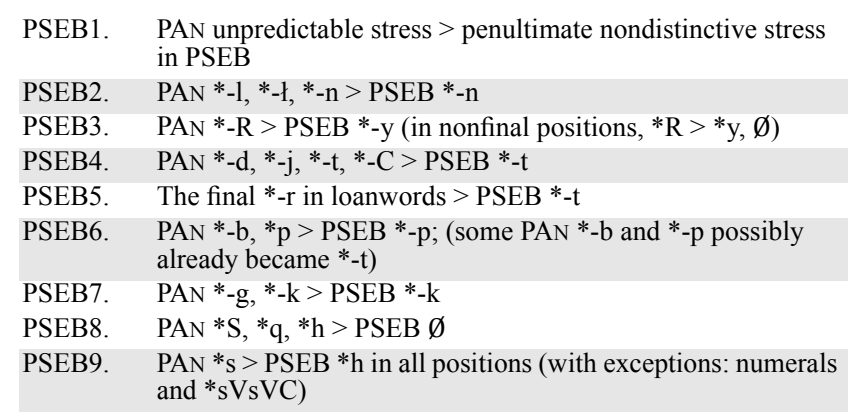

As far as PSEB1 is concerned, PAN stress, according to Wolff (2010), could fall on any of the last three syllables of a word. He does not specify whether it was contrastive. Blust does not reconstruct stress for PAN. He considers stress to have been on the penultimate syllable, or on the last syllable if the penultimate vowel was a schwa. In SEB languages, stress is not contrastive. It plays a minor role in MNY, where it is on the penultimate syllable as a rule. Dahl (1951:88) points out that, historically, MLG stress derives from the same pattern as the one pertaining to MNY. It is consequently possible to reconstruct noncontrastive penultimate stress for PSEB. (See below for a more detailed description of stress developments in MLG).

The following exemplify PSEB2, the merger of PAN *-1, *-1, *-n as PSEB *-n:

12. For the sake of maintaining an empirical basis that is maximally strong, I should also have included data from other SEB languages. Considerations of space prevent me from doing so within the limited scope of this article. The reader is referred to Dahl (1977) and Mahdi (1988) for comparative analyses of the SEB data. From my own observations based on fieldwork and the analysis of liturgical texts (Adelaar 1995b), MNY and Samihim are mutually understandable dialects of the same language and are more closely related to MLG than other forms of SEB. 
(3) PMP *katəl 'itchy' > PSEB *katen > MNY katen 'eroding', MRN hàtină 'scabies'

PMP *təbəl 'dense, crowded' (Proto-Philippines [Blust and Trussel in progress]) *təbəl 'constipated'; MAL təbal, JAV təbəl 'thick, dense' ) $>$ PSEB *tewen $>$ MRN tèvină

PAN *kaS(ə)pal 'thick, of solid objects' > PSEB *kapan > MNY kapan 'big; numerous'.

PAN *bulat 'moon; month' > PSEB *wulan > MNY wulan, MRN vùlană

PAN * quzał 'rain' > PSEB *uran $>$ MNY uran, MRN ùrana

PAN *Cawił 'year' $>$ PMP *taqun $>$ PSEB *taun $>$ MNY taun, MRN tàună

PAN *kan 'to eat'> PSEB *kan $>$ MNY k<um $>$ an, MRN h<ùm $>$ ană, $\mathrm{h}<$ ìn $>$ ană

PAN *ajan 'name' > PSEB * y/aran > MNY yaran, MRN anàrană

$\mathrm{PAN} *$ daSun 'leaf' $>\mathrm{PSEB} *$ rawen $>\mathrm{MNY}$ rawen, MRN ràvină

Some words lost *-l altogether in MLG. Most likely, these are Malay loanwords that were borrowed at a stage in which inherited *-1 had already become *-n in SEB languages. Examples:

(4) $\mathrm{PMP} * \mathrm{cu}(\mathrm{y}) \mathrm{kil}$ 'to poke' (Dempwolff 1938) > tsùki 'pointed'13

PMP *paykal 'root' (Dempwolff 1938) > faka (but compare also MAL paykal 'root, basis' as a possible source).

Change PSEB3, *-R > *-y, is exemplified below:

(5) PMP *niuR 'coconut; coconut palm' > PSEB *niuy $>$ MNY niui, MRN vua/nìhu (with apparently orthographic $h$ )

PMP *saluR 'pond, lake' (Dempwolff 1938) > PSEB *haluy 'to pour, moisten' > MNY halui 'pour in!' MRN mi-àlu 'to moisten', alùz-ină 'poured over with gravy, of rice'

PMP *dəyəR 'to hear' > PSEB *reney > MNY renei, SSK tan/drène 'to obey’ (Dahl 1951:82), Tsimihety naha-rèni 'hear' (Dahl 1951:82)

Examples of change PSEB4, the merger of *-d, *-j, *-t, *-C as PSEB *-t, are:

(6) $\mathrm{PMP} *$ qatəd 'to bring, accompany' $>$ PSEB *atet $>$ MNY atet, MRN àtitră

PMP * pənəd 'plugged up' $>$ PSEB penet $>$ MRN fènitră (see above)

PMP *pusəj 'navel; center' > PSEB * puhet $>$ MNY puhet 'navel', MRN fùitră

PMP *laləj 'fly' > PSEB *lalet > MNY lalet, MRN lalitră

PMP *qotut 'fart' > PSEB *k-etut (with prefix *k(a)- indicating nonvolitional action?) $>$ MRN h/ètutră

PAN * Rabut 'to uproot' > PSEB *awut > MRN àvutră 'to uproot', avùt-ană 'uprooted'

13. The status of this etymon is extremely doubtful. Dempwolff reconstructed it on the basis of MAL, JAV, Ngaju (southern Borneo), and MLG reflexes only. JAV, Ngaju, and MLG are all West Indonesian languages and have undergone substantial lexical influence from Malay. Moreover, PMP *c (Dempwolff's * $\mathrm{k}$ ') is a weak protophoneme per se, and many MLG words containing $t s$ (except for those preceding $i$ ) are loanwords or onomatopoeic words. 
PAN *uRaC 'vein' > PSEB *uyat > MNY uwat (with [originally nonphonemic intervocalic] glide) 'vein, root', MRN uzatră 'vein, nerve, tendon'

PAN *SəpaC 'four' > PSEB *epat > MNY epat, MRN efatră

Note that MNY and MRN have different reflexes of * $\mathrm{R}$ in *uRaC (> PSEB *uyat). There are other instances where they differ in reflecting PSEB *y or $\emptyset$. They indicate that both languages already had separate histories in premigratory times. ${ }^{14}$

The mergers of PAN *-d, *-j, *-t, *-r (a loan phoneme) as *-t, *-g and *-k as *-k, and *-b and *-p as *-k or *-t, have clearly taken place in all MLG dialects. MNY exhibits $-p,-t,-r$, and $-k$, but a closer look shows that the same mergers as in MLG also apply to at least some MNY words. Most likely, the mergers of *-p, *-r, and *-t as *-t were well on the way in both early MLG and early MNY at the time when MLG speakers sailed to East Africa, but were later stopped (and partly reversed?) in MNY through the influence of Malay loanwords later on, which brought about the reintroduction of $-p$ and $-r$, among other consonants.

In the following MAL and JAV loanwords, final $r$ became $t$ in MNY (PSEB5):

(7) MAL bayar 'to pay' > MNY wayat, mañat ${ }^{15}$

MAL butir 'grain' $>$ MNY butit 'a (little) bit' 16

OJ həlar, JAV əlar 'wing' > Banjar MAL halar, MNY elat, MRN èlatră;

MAL pə-latar-an 'unroofed and unrailed verandah or raised platform attached to a Malay house', JAV latar '1. front yard; 2. base, background' > MNY natat (Rubay et al. 1997).

This is not the default correspondence: MNY maintains final $r$ in many other loanwords originally having this sound. What the above three cases demonstrate is that, at some stage in the history of MNY, final $r$ in loanwords must have merged with final $t$, but this change halted under the weight of the heavy and continuous MAL influence that followed. MLG, on the other hand, apparently also went through this initial stage, but in this language it persisted, as it escaped the subsequent MAL influence that has shaped modern MNY. As a result, it regularly merged final $r$ in MAL loanwords with *-t to -tră. As this merger applied to both MNY and MLG simultaneously, we conclude that it took place in premigratory times.

Some examples of PSEB6, the merger of *-b and *-p as PSEB *-p, are:

(8) PMP *unkab 'to open' > PSEB *ukap > MRN s/ùkatră (s/ukàf-ană)

PMP *labləb 'to dive, submerge' > PSEB *lelep > MRN lèlikă (lelèfană) 'covered'

PMP *tuptup 'to cover' > PSEB *tutup > MNY ba-tutup 'to have a lid', MRN tùtutră (tutùf-ană) 'to cover'

PMP *alap 'to take' > PSEB *alap > MNY alap, Betsileo MLG àlakă

PMP *səpsəp 'to suck' > PSEB *sesep > MNY hehep, MRN sèsitră 'to smoke hemp'

14. According to Mahdi (1988:161), PAN nonfinal *R regularly became $\emptyset$ in SEB languages, and where the latter exhibit $y$ instead, this is due to borrowing from other neighboring Barito languages.

15. In MNY (and in the history of MLG), prenasalization also causes the nasalization of a following $y$ if the surrounding vowels are identical; cf. also huyu, тип̃ ' to order' $(<\mathrm{PMP}$ *suRuq 'to order'); ayak, yañak 'to invite; to lead' (Rubay et al. 1997).

16. Malay butir is a regular reflex of PAN *buCeliR 'wart; cyst; non-purulent'. Note that MNY and MLG also have regularly inherited reflexes, wusi and vutsi (same meanings), respectively. 
Two other cases suggest that the merger of final labials and coronals as *-t observed in some MLG roots may occasionally also have occurred in MNY, and that this merger was already going on in premigratory times. However, much more evidence would be needed to establish this as a fact. The cases are as follows:

(9) MAL tabip 'physician, doctor' (ultimately from Arabic țabīb) > MNY tabit

PMP *alap 'to take away' > MNY k/alat, Bayan alat, MRN hàlatră 'to steal' (see above) ${ }^{17}$

Some examples of PSEB7, PAN *-g, *-k>*-k, are: ${ }^{18}$

(10) PMP *kudug 'detonation' $>$ MRN kùtrukă 'thunder'19

PAN *ałak 'offspring' > PSEB *anak > MNY anak, MRN ànakă

PMP *tasik 'sea, salty water' > PSEB *tahik > MNY tahik, MLG (eastern dialect) tàiki (Dahl 1951:317)

PMP *nunuk 'a tree, the banyan' > PSEB *nunuk > MNY nunuk, SSK nùnukĕ 'k.o. tree with big trunk, Ficus megapoda Bac. (Moraceae)'

Some examples of PSEB8, loss of *S, *q, and *h, are:

(11) PAN *CaliS 'rope' $>$ PSEB *tali $>$ MNY, MRN tàdi, SSK tàli

PAN *qapəjuS 'gall' > PSEB *aperu $>$ MNY aperu, MRN afèru

PAN *ludaq 'spittle' $>$ PSEB * rura $>$ MNY rura, MRN rùra

PAN *bajaq 'to inform' > PSEB *wara > MNY wara? ${ }^{20}$ MRN am/bàra 'revealed, declared'

PMP *asiq 'compassion' > PSEB *a(s,h)i > MNY àhi, SSK àsi 'honor' (D51:344)

PAN *baRah 'embers' $>$ PSEB * waye $>$ MNY wayä, waye $>$ (PMLG *waye $>$ ) SSK vàe, MRN vai-n-àfu, mi-vai-vài 'to glow with heat, incandescent'

PAN *baqəRuh 'new' > PSEB *wau 'new; recently' > MNY wau, MRN vàu 'new, recently' 21

PAN *kalih 'to dig' > PSEB *kali > MNY kadi, MRN hàdi 'pit, hole, ditch, mi-hàdi 'to dig', SSK hàli 'pit, hole'

Examples of PSEB9, ${ }^{*} \mathrm{~s}>* \mathrm{~h}$ in all positions, are:

(12) PAN *sapaw 'field hut' > PSEB *hapaw 'roof' > MNY hapaw, MRN t/àfu ${ }^{22}$

PAN *sida 'they' > PSEB *hire $>$ MNY here (with vowel assimilation), $\operatorname{MRN}(*$ ire + ito $>$ ) irèto 'these (quite near in sight)'

PMP *asiq > PSEB *a(s,h)i > MNY àhi, SSK àsi (see above)

17. Note, however, that when this verb is suffixed, no $-f-(<*$-p- $)$ reappears if the suffix is vowelinitial: for example, halàr-ană 'stolen'.

18. Note that PAN/PMP etyma ending in *-g are extremely rare and usually of a doubtful status.

19. No MNY reflex; very doubtful etymology on account of irregular $k$ - and $t r$.

20. The final glottal stop is not historical. Final glottal stop accretion is a widespread phenomenon in SEB languages (and in other languages in Borneo, including various Malayic ones).

21. Note that PSEB *-au and MNY, MRN - $a u$ are not diphthongs but indicate two syllables.

22. Note that $t(a)$ - may have been added to avoid a homonymic clash with afu 'fire' (Dahl 1951:313). 
PAN *qasəy 'breath' > PSEB *ahey > MNY ahen 'soul, mind', MRN àină 'breathing, life', SSK ài

PMP *ləpas 'free, released' > PSEB *lepah > MNY lepah 'released; not able, lack the power' (Rubay et al. 1997), MRN man-dèfa 'to release', mi-lèfa 'to flee'

PMP *Ratus 'hundred' > PSEB *yatuh $>$ MNY jatuh $(j$ - remains unexplained), MRN zàtu

All the above examples exhibit lenition in MNY and loss of *s in MLG. This is the regular reflex of *s in inherited vocabulary in these languages, although there are exceptions (see section 6). In contrast, loanwords tend to maintain *s in both MNY and MLG, although there are loanwords showing loss of *s in either MNY or MLG, or both:

(13) MAL sunay 'river' ${ }^{23}>$ MNY huje, MRN ùni

MAL sakay 'subject, dependent (of subject people in contrast to the ruling race' $24>$ MNY hake 'foreign (Muslim) trader operating in the Barito area' (Adelaar personal fieldnotes), MRN sakaiza 'friend; paramour'25

MAL sorak 'to shout' > MNY surak 'outcry of joy', MRN h/ùrakă 'emotional shout 26

MAL sampay 'to hang down; to reach; until, sufficient' > MNY hampe 'to arrive; complete; until; so that', MRN àmpi 'complete, sufficient, enough; towards' (see also section 8).

See section 6 for a further examination of *s reflexes.

The changes that took place in PMLG are postmigratory. These are given in table 4, and are labeled PMLG1, PMLG2, and so on. ${ }^{27}$

\section{TABLE 4. RELEVANT CHANGES IN PMLG}

PMLG1. PSEB *-p > PMLG *-k, *-t (possibly already started before, see above)

PMLG2. PSEB * $\mathrm{h}>$ PMLG $\emptyset$ in all positions

PMLG3. PSEB *-u, *-aw, *-uy $>$ PMLG *-u

PMLG4. PSEB *-ey, *-e > PMLG *-e

Some examples of PMLG1, PSEB *-p > PMLG *-k or *-t, are:

(14) PSEB *lelep 'to dive, submerge' > PMLG *lelet (*lelef-an) 'covered' PSEB *tutup 'to cover' $>$ PMLG *tutut (*tutuf-an) 'to cover'

MAL tankap 'to seize, grab' > PMLG *takat (*takar-en) 'to reach'

PSEB *sesep 'to suck' > PMLG *seset 'to suck, smoke'

23. This is probably a MAL loanword. Dempwolff has PMP *t'unay 'river', with reflexes only in Toba Batak, Ngaju, MAL, and MLG (Toba Batak and Ngaju have also borrowed substantially from MAL).

24. This is Wilkinson's definition; however, the term apparently had a wider meaning and referred to any dependent of any ruler (Waruno Mahdi pers. comm.).

25. This set ultimately derives from Sanskrit sakhāy- (and its accusative case form sakhāyam) 'friend, assistant, companion' (Gonda 1973:418).

26. The MRN form has the nonvolitional prefix *ka- $>h$ - (?). The form must be borrowed on account of the $r$ reflex.

27. This term refers to any stage after SEB speakers had sailed to East Africa. Note that substantial lexical evidence supporting some of the PMLG etyma in table 4 was already provided earlier in this subsection. 
PSEB *lelap 'to lick' > PMLG *lelak (*lelaf-en)

PSEB * raprap 'to detach' > PMLG *rarak (*raraf-an, *rarah-an) 'to be detached'

PSEB * raqup "to collect, bring together $>$ PMLG *rauk (*rauf-en)

PSEB *sisip 'to insert, stick into something' > PMLG *sisik (*sisih-an, *sisif-an)

Examples of PMLG2, the loss of PSEB *h, include:

(15) PSEB *hire 'they' > PMLG *ire

PSEB *ahen 'breath' $>$ PMLG *aen

PSEB *lepah 'free, released' > PMLG *lefa

PSEB *yatuh 'hundred' > PMLG *yatu

Some examples of PMLG3, the merger of PSEB *-u, *-aw, and *-uy as PMLG *-u, are:

(16) PAN *Coluh 'three' $>$ PSEB *telu $>$ PMLG *telu $>$ MRN tèlu (cf. MNY telu)

PAN *pitu 'seven' $>$ PSEB *pitu $>$ PMLG * fitu $>$ MRN fitu (cf. MNY pitu)

PMP *qalojaw ‘day' > PSEB *anraw $>$ PMLG *andru (cf. MNY anraw)

PSEB *hapaw 'roof' > PMLG *t-afu

PWMP *lalaw 'to surpass; pass; past; gone' > PSEB *lalaw 'to pass' > PMLG *lalu 'to pass, hurry along' (*laluv-an) $>$ MRN làlu 'to pass without stopping' (lalùv-ană) ${ }^{28}$

PAN *Sapuy 'fire' > PSEB *apuy $>$ PMLG *afu $>$ MRN àfu

PAN *babuy 'pig' $>$ PSEB * babuy $>$ PMLG *vavu $>$ East MLG vavomay 'sow' (< vavu 'pig' + mai 'mother' [<Portuguese]); (Houtman 1603)

PMP *lanuy 'to swim' $>$ *PSEB *lanuy $>$ PMLG *lanu, *lanuy-en $>$ MRN mi-1<um>ànu (lanùs-ină) (with -s- instead of expected $-z$-).

Examples of PMLG4, PSEB *-ey, *-e > PMLG *-e, include:

(17) PMP *pajay 'riceplant' > PSEB *parey > PMLG *pare (meaning shifting towards 'sugarcane') (cf. MNY parei 'rice [plant as well as grain])'

PAN *m-aCay 'dead' > PSEB *matey > PMLG *mate (cf. MNY matei)

PMP *teytey 'suspension bridge' > PSEB *tetey 'to cross' > PMLG *tete 'to cross', *tetey-an 'bridge' (cf. MNY i-tetäi 'to communicate, convey; about')

PSEB *waye 'embers' > PMLG * waye $>$ MRN vài, SSK vàe

PAN *duSa 'two' > PSEB *rue > PMLG *rue (cf. MNY ruäh [- $h$ unexplained])

The changes that have been taking place in different ways in the various MLG dialects are shown in table 5, and are labeled MLG1, MLG2, and so on.

\section{TABLE 5. RELEVANT CHANGES IN MLG}

MLG1. Tendency to merge original final nasals

MLG2. PMLG *-t $>r$ (in Old SBM), $t r \mathrm{~V}, t s \mathrm{~V}$ (in the other dialects; where $\mathrm{V}=$ paragogic vowel)

MLG3. PSEB noncontrastive penultimate stress $>$ unpredictable, contrastive stress on any of the last three syllables

MLG4. PMLG*-e, *-i > MRN -i, SBM - $e$; in SSK, *-i and *-e are still distinguished

28. MNY ba/lalu must be borrowed from Banjar Malay on account of final $u$ and the Banjar Malay intransitive prefix $b a-$. 
The tendency to merge *-m, *-n, and *-n (MLG1), has affected MLG dialects in different ways (see ). SBM still distinguishes $-n$ and $-\eta$, and, in Flacourt's (1658) dictionary, also $-m .{ }^{29}$ Other dialects distinguish *-n and * $-\mathrm{n}$, but have merged *-m with *-n or *-n. The merger of final nasals was total in MRN, which only has -nă. In southwestern MLG dialects such as SSK, word-final nasals were lost.

Dialects distinguishing *-n and *-n sometimes substitute *-n for *-n. In MRN, *-m sometimes reemerges before a suffix, and so do *-m and ${ }^{*}-\mathrm{n}$ in other MLG dialects. (Note that in MRN, ${ }^{*} n$ and ${ }^{*} \mathrm{y}$ have also merged as $\mathrm{n}$ in intervocalic position, whereas in most other dialects they have not; see below). From the fact that all three final nasals were still extant in Old SBM, we infer that they were also present in Proto-MLG, and that the tendency to merge final nasals is an entirely postmigratory development.

With the change MLG2, final *-t became -tri in northern dialects (Tsimihety MLG, NSK), and -tră in MRN; it became -tsě or -tš̆ in southwestern dialects (SSK, Bara MLG, Antandroy MLG), and a "mute $r$ " in SBM (Dahl 1951:65; Ruud 1955:35), although Old SBM has a corresponding -ts or -te). See for examples. The paragogic vowels added to the few consonants left in final position are different in individual dialects (see 2.2 and ).

Change MLG3 concerns stress. As noted by Dahl (1951:88), in historical hindsight, MLG stress was penultimate, as it still is in MNY and other SEB languages in Kalimantan. In Wolff's (2010:451) words, "stress is predictable in terms of the make-up of the word." Modern MLG dialects have traded the regular and noncontrastive antepenultimate word stress pattern of PSEB for a contrastive one.

MLG stress can be on any of the last three syllables of a word. However, its position is still partly predictable, and it would be entirely so were it not for vowel contraction and the occurrence of loanwords.

Generally, words ending in a paragogic vowel have antepenultimate stress: for example, làlană 'road' ( $<$ PSEB *lalan), lànitră 'sky' ( $<$ PSEB *lanit). If they have only two syllables, stress is on the penultimate syllable (such words have usually undergone vowel contraction); examples: ùtră 'to massage' ( $<$ PMLG *uut $<$ PMP *quRut); mi-fună 'to beg pardon' ( $<$ PMLG *fuun 'forgiveness' $<$ PMP *puqun?; cf. Banjar MAL puhun, muhun 'to beg forgiveness'?) (cf. Adelaar 1992:48, fn.90, also p. 109). Other words have penultimate stress unless they are monosyllabic; for example, dimi ' five' $(<$ PAN *lima 'hand; five'); vìlu 'hair' ( $<$ PMP *bulu 'body hair; feather, fur'); fànă 'heat' ( $<$ PMP *panas); fü 'heart' ( $<$ PSEB *puhu $<$ PMP *pusuq).

Loanwords sometimes break the pattern outlined above and have added to the unpredictability of stress placement and the contrastiveness of stress. Examples of contrastive stress are làlană 'road' ( $<$ PAN *zalał) vs. lalànă 'law' ( $<$ ? French la loi 'the law'); ${ }^{30}$

29. Dahl's (1937:200) claim that *-m is also still extant in Houtman's East MLG wordlist is not substantiated by the data: while this source does contain one word with final -m (mynom 'to drink' $<$ PAN *inum), other words with historical *-m reflect this as $-n$; for example, wellon 'to live' (<*belum), ennin 'six' (<*ənəm), and hallin 'night' $(<*$ qaləm). Flacourt (1658), on the other hand, has Old SBM velome 'lively', enem 'six', and halem 'night'; curiously enough, this source also has minon 'to drink'. Houtman's mynom must be a MAL word that inadvertently ended up in Houtman's MLG list (on account of its initial $m$, which also appears in MAL minum but not in MRN inună or related forms in other MLG dialects).

30. The form lalànă is generally considered to reflect French la loi (cf. Richardson 1885). Dahl (1951:91), however, believes that it is derived from làla, cf. maha-làla 'to know'. 
tànană 'hand' (<MAL tanan) vs. tanànă 'village' (<MAL tanah + *-an, cf. Dahl 1951); kibày 'stick' ( $<$ ?); dité 'tea' $(<$ French du thé).

Suffixation causes stress to shift to the right; for example, mi-vèluna 'to live' vs. velùm-ină (undergoer voice form). No stress shift happens in modern MLG if a root with historically contracted vowels is suffixed; for example, mi-fun ă 'to beg pardon' ( $<$ PMLG *mi-füun) vs. i-fün-ană 'to be begged pardon of' (circumstantial voice form) (<PMLG *i-fuùn-an). The net effect of all this is that, in derivations involving suffixation, stress is always on the syllable directly preceding the suffix (even if the latter is disyllabic).

Examples of MLG4 are:

(18) PMP *siwa 'nine' $>$ PSEB * siwe $>$ MNY suei, PMLG * siwe $>$ MRN sìvi, SSK sìve, $\mathrm{SBM}$ * sìve

PMLG *rue 'two' $>$ MRN rùa (with unexplained $-a$ ), SBM rùe, SSK rùe

PAN * pija 'how much/many?' > PSEB *pire , MNY pirä > PMLG *pire $>$ MRN firi, SBM fire, SSK fire

PSEB * waye 'live coal' > PMLG * waye $>$ MRN vài, SSK vàe

PMLG * tete 'to cross', *tetey-an 'bridge' > MRN tèti, SSK tète 'to cross', MRN tetèz-ană, SSK tatèz-a 'bridge'

PSEB *parey 'riceplant' > PMLG *pare (meaning shifting towards 'sugarcane') $>$ MRN färi, SSK fàre 'sugarcane'

PSEB *matey 'dead' > PMLG *mate > MRN màti, SSK màte

PMP *qabis 'all' > PSEB *a(bw)ih 'each; all' > PMLG *awi > MRN àvi, SBM àbe, SSK àbi, i/àbi

PSEB *kali 'to dig' > MNY kadi, PMLG *hali, *hadi 'pit, hole, ditch' > MRN hàdi, mi-hàdi 'to dig', SSK hàli 'pit, hole', SBM angàde 'digging stick'

The changes that took place in MRN in particular are shown in table 6 and are labeled MRN1, MRN2, and so on.

Examples of MRN1 are:

(19) PAN *ajan 'name' > PMLG *ay/aran > MRN anàrană (cf. SSK anàra, SBM anàrană)

MAL tanan 'hand' > PSEB ?, MNY tanan > PMLG *tanan > MRN tànană (cf. SSK tàna)

PAN *bulał 'moon; month' > PMLG *wulan > MRN vùlană (cf. SSK vùla, $\mathrm{SBM}$ vùlan)

JAV wulan 'instruction' > PMLG * wulan 'word' > MRN vùlană (cf. SBM vùlay, SSK vùla)

Examples of MRN2 are:

\title{
TABLE 6. RELEVANT CHANGES IN MRN
}

\author{
MRN1. PMLG * $\mathrm{n}, *^{\mathrm{n}}>n$ in all positions \\ MRN2. PMLG *-m, *-n, ${ }^{*}-\mathrm{n}>n(-m-,-n$-, before a suffix $)$ \\ MRN3. PMLG *y (in all positions) $>z$ \\ MRN4. PMLG *-e $>-i$
}


(20) PSEB *welum 'to live; lively' > MNY welum, PMLG *welum, > MRN vèlună, SSK vèlu, Old SBM velome 'vivacious' 31

PAN *ənəm 'six' > PSEB *enem > MNY enem. PMLG *enem > MRN ènină, SSK ène, Old SBM enem ${ }^{32}$

PAN *haləm 'night' $>$ PSEB *alem $>$ MNY alem, PMLG *alem $>$ MRN àlină, SSK àle, Old SBM halem ( $h$ - unexplained).

The following are examples of MRN3:

(21) $\mathrm{PMP} * \mathrm{si}$ '(personal article)' $>$ PSEB *hi $>$ MNY hi, PMLG *y- $>$ MRN z/-33 PMLG *yatuh 'hundred' $>$ MRN zàtu

MAL kayu 'wood; tree' > MRN hàzu (cf. SBM kayo; Ruud 1951)

PSEB *uyat 'vein' > PMLG *uyat 'vein, nerve, tendon' > MRN ùzatră

PMLG *tetey-an 'bridge' $>$ MRN tetèz-ană

PSEB *haluy ‘to pour, moisten' > PMLG *alu (*aluy-en) $>$ MRN mi-

àlu 'to moisten', alùz-ină 'poured over with gravy, of rice'

Note, incidentally, that nonfinal PAN *y was lost in PSEB, and that PSEB and PMLG *y- and *-y-do not reflect PAN/PMP *y. Dempwolff $(1937,1938)$ and Wolff(2010) analyze this differently, but my analysis agrees with Mahdi (1988:150), who also pointed out that MNY ka-kau 'tree' is the inherited reflex of PAN *kaSiw, whereas MNY kayu and MLG hàzu were borrowed from Malay.

Note also that PMLG *y is still reflected as $y$ in the Old Taimoro writings in Sorabe script and in part of the vocabulary of SBM.

The following exemplify the change MRN $4,{ }^{*}-\mathrm{e}>-i$ :

(22) PMLG *pare ('riceplant'? 'sugarcane'?) > MRN färi (cf. SSK fàre)

PMLG *waye 'live coal' > MRN vài (cf. SSK vàe)

PMLG * tete 'to cross' > MRN tèti 'id. (cf. SSK tète)

PMLG *mate 'dead' > MRN màti (cf. SSK màte)

However, the change from PMLG *-e to MRN $-i$ did not take place in a case like $f e$ 'hip, hind (leg)', in which the final stressed $e$ is the result of vowel contraction; compare:

(23) PSEB *pee hip, hind(leg)' > MNY pee, PMLG *pee > MRN fe, Old Taimoro MLG fee, ${ }^{34}$ SSK elakela-pè (lit., 'between-legs') 'crotch'

\section{THE SPIRANTIZATION OF STOPS AND FRICATIVIZATION OF}

SEMIVOWELS. In Wolff's analysis, the spirantization of stops and fricativization of semivowels in MLG was not due to contact. He points out that "the change from *b and *d to $v$ and $r$ must have taken place before the migration west" (2010:455), and argues that other instances of spirantization and fricativization in MLG are very different from

31. Compare also the undergoer forms MRN velùm-ină, $\mathrm{SSK}$ velùm-e.

32. Compare also MRN h-enèm-ană 'the sixth day' (Dahl 1951:282).

33. For example,. *si *anak '(the) child' > PSEB *hi anak $>$ PMLG *y-anak $>$ MRN z/ànaka.

34. Ferrand (1904) transliterates this word as $f e$, but its original spelling clearly indicates that it had a double vowel. This conclusion is based on the fact that in the Sorabe (Arabic) text presented in Ferrand (1904), vowels are always indicated with diacritics, never with the full letters waw $(w)$ and iod $(y)$. The latter are as a rule only used for (i) semivowels and (ii) phonemic glides. In the only words in which it indicates a vowel, historical evidence clearly shows that this vowel must have been long or geminated; compare fuu 'heart' $<$ PMLG *fuu $<$ PSEB * puhu; fee 'hip, hind leg' < PMLG * fee < PSEB * pee. 
similar looking instances of spirantization and fricativization in Comorian languages, and should therefore be treated as unrelated events. In this analysis, the change from * $\mathrm{k}$ to $h$ would be the only instance of spirantization shared between Comorian and MLG (cf. Nurse and Hinnebusch 1993:71-73), and should therefore be attributed to chance.

Wolff's view on these developments is clearly limited by the fact that he only considers sound correspondences directly between PAN and MLG, without paying attention to what happened in intermediate stages. That the weakening of PAN *b and *d is a PSEB development and therefore happened before the migration is something we have known since Dahl (1951). It is also made clear in Dahl (1977), Hudson (1967), and Mahdi (1988). However, it involved a change from $* \mathrm{~b}$ to $* \mathrm{w}$, not one from $* \mathrm{~b}$ to $v$, as the fricativization of semivowels only happened after the migration. In more general terms, the spirantization of stops other than *b and *d, as well as the fricativization of semivowels, are processes that took place after the migration, and they did so in a contact situation involving both MLG and Comorian languages. ${ }^{35}$

Furthermore, contrary to Wolff's argumentation, there are actually many instances of spirantization and fricativization common to MLG and Comorian.

Insofar as a $k$ has not become $h$, it palatalizes to varying extents in both MLG and Comorian in the presence of $i$ : in MLG, $k$ is pronounced [ $\left.\mathrm{k}^{\mathrm{y}}\right]$ before or after $i$; in Comorian, ${ }^{*} \mathrm{k}$ has become $\left[\mathrm{k}^{\mathrm{y}}\right]$ or [ $\left.\mathrm{s}\right]$ before ${ }^{*} \mathrm{i}$ (Nurse and Hinnebusch 1993:73-80).

Proto-Sabaki *p became Shindzuani $v$, other Comorian $\beta$. According to Nurse and Hinnebusch (1993:63-67), this must have happened via an intermediate stage in which *p became * $\phi$. As such, this development is comparable to the one from PAN *p to MLG $f$, which must also have gone via an intermediate $* \phi$ stage. Compare, for instance, North Betsimisaraka, which still has a reflex $\phi$ for PAN *p (Kikusawa 2006:8).

In Comorian languages, Proto-Sabaki *c became ts (Nurse and Hinnebusch 1993:82-88); in MLG, $c$ in MAL loanwords became ts or $s$; for example, MAL bicara 'deliberation; legal proceeding, court case' > mi-tsàra 'to judge'; MAL cupin 'ear-lobe' > sùfină 'outer ear' (PMP *c is not reflected in inherited MLG vocabulary).

In Comorian, *g became $\emptyset$, sometimes $h$, and obviously via a stage in which *g became *h (Nurse and Hinnebusch 1993:104-8). In MLG, MAL $g$ usually became $h$ and is often not pronounced at all.

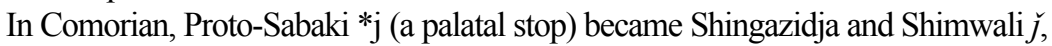
Shindzuani, Shimaore $\check{z}$ (Nurse and Hinnebusch 1993:108-12). In most MLG dialects, the Proto-MLG semivowel and loan phoneme *y became $z$. However, this change never fully took place in the SBM dialect (nor in the southern Tandroy dialect, or in the eastern Old Taimoro dialect as represented in the Sorabe script). It therefore seems to be a rather recent change, which is not representative of PMLG.

4. THE ORIGINS OF THE RETROFLEX AFFRICATE $\boldsymbol{t}$. The developments leading to MLG $t r$ are more complicated. This is a retroflex affricate, which also

35. This recent spirantization in Comorian languages is not to be confused with the so-called Bantu Spirantization process, a much earlier change that affected many Bantu languages, including all Sabaki ones. Its manifestations are very different from the spirantization under discussion (cf. Nurse and Hinnebusch 1993:113-33). 
occurs in Comorian languages. In MLG, it reflects original $d$ in MAL loanwords; in Comorian, it evolved from an earlier *t. Examples of MAL $d>$ MLG $\operatorname{tr}$ (cf. Adelaar 1989) include:

(24) MAL dada 'chest' $>$ MRN tràtra, MNY dada? (Adelaar 1989:12)

MAL duyun 'dugong; sea-cow'> MRN trùzună 'whale' (Adelaar 1989:17)

(Sanskrit duṣa 'sin' >) MAL, JAV dosa 'sin' > MRN trùsa 'debt' (Adelaar 1989:17)

MAL (məm-)bidik 'to aim', ${ }^{36}$ Banjar MAL bidik 'accurate in aiming' > MRN vitrikă 'vigor, dynamism, promptness'

Wolff (2010:456) is skeptical about Bantu influence on the development of MLG tr and notes that neither Dahl (1951) nor Adelaar (2009a) cite any facts to explain why Bantu should be responsible for the development of $t r<\operatorname{MAL} d$.

I would like to speculate that the change from MAL $d$ to $t r$ happened in two stages, one of which preceded the migration, and the other followed it. It should be recalled that PSEB was left without $*_{d}$ after PAN $*_{d}$ had become $*_{r}$ and $*_{-t} t$ in this protolanguage. It should also be noted that, in MAL and many other Austronesian languages, $d$ and $n$ are alveolar, whereas $t$ is interdental.

In a premigratory stage, the $d$ in MAL loanwords may have been perceived as a retroflex and borrowed as such in early MLG; a similar phenomenon is observed in Malay and Dutch words borrowed into Javanese, which also have a retroflex $d$ for the alveolar $d$ in their respective source languages (Adelaar 1995a). The retroflex $d$ in some JAV words borrowed into MLG is also rendered as tr; for example, JAV saday 'the dwarf fan palm (Livistonia rotifundifolia Mart.)' > MRN sàtrană 'fan palm' $\cdot{ }^{37}$ Circumstantial evidence for a retroflex interpretation of $d$ in early MLG may be that the Sorabe or Onjatsy script, which is the MLG adaptation of the Arabic script, uses the same graphemes for $d$ and $t$ as the Pégon script (the JAV adaptation of the Arabic script) does for retroflex $d$ and $t$, respectively (Adelaar 1995a). ${ }^{38}$

The affricatization of * $\operatorname{de} t r$ must have happened in East Africa in a postmigratory stage. It may be due to Comorian influence, since Comorian languages also have a tr. However, in the latter it is also a recent development. It is not shared with Kiswahili and clearly took place after the Proto-Sabaki split-up. According to Nurse and Hinnebusch (1993:70), Comorian tr may represent a change in progress from Proto-Sabaki *t to $r$, which seems to be manifested in different stages by various Sabaki subgroups. But it could also be due to influence from Makhuwa. This is a non-Sabaki language also exhibiting $\operatorname{tr}$ (van de Velde 2009). It must have had some influence on MLG, as it was the mother tongue of many imported slaves in Madagascar as well as a lingua franca to

36. Cf. Wilkinson (1959) bidek, bedek 'to close one eye, e.g., when aiming a gun or looking through a telescope'.

37. Laurie Reid alerted me to another instance of the tendency of *d to become a retroflex with fricative realization. In Manobo, intervocalic $d(<\mathrm{PAN} * \mathrm{~d})$ is written as $z$ in Elkins (1968) but is pronounced as a voiced retroflex fricative. Philippine languages fit into the general Austronesian pattern of having an interdental $t$ and alveolar $d$; on the other hand, $s$ is a retroflex. As Reid (pers. comm.) points out, the tendency of $d$ to become a retroflex fricative may be motivated by an urge to match $s$ as its voiceless counterpart.

38. However, the evidence is rather indirect and needs further contextualization, as $t r$ itself is rendered by a geminated $r$ sign in Sorabe. 
slaves with other linguistic backgrounds who ended up on this island. It may have had influence on some phonological developments in MLG (and Comorian?), such as the development of $t r .{ }^{39} \mathrm{Be}$ that as it may, in MLG the affricatization of this phoneme is most likely due to recent influence from a Bantu language.

\section{THE REDUCTION OF HOMORGANIC NASAL + VOICELESS}

STOP CLUSTERS. Wolff's skepticism is also based on another change that he cannot explain through Bantu influence, the reduction of *-nk- clusters to $k$ in MAL loanwords. Although Wolff does not make this explicit, this reduction is not limited to *-nk-, but also concerns some *-ng- clusters in MAL loanwords; for example, MAL tungal 'one, single, only' > MNY tonkan (inherited, or early adaptation?), tongal, MRN tùkană; MAL tanguy 'to carry on the shoulders' > MNY tangon 'to carry', MRN tàkună 'to carry (of many)'). It also happened in Comorian but, as Wolff notes, only in Shimaore, the dialect of Mayotte Island, where it is moreover part of a more general cluster reduction also involving *-mp- and *-nt. ${ }^{40}$ In Wolff's assessment, "although it remains a mystery why MLG has borrowed ML [ = MAL] forms containing $/ \mathrm{jk} /$ with $/ \mathrm{k} /$, it is not likely that the development in the [Shimaore] dialect or any of the other Sabaki languages had a hand in it if the other clusters were not simplified as well" (Wolff 2010:455). Wolff is referring to MRN. However, a more general reduction of homorganic nasal + stop clusters is exactly what happened in nonstandard dialects such as Bara (Eli 1988) and, somewhat less systematically, in the dialects of South East Madagascar (Dahl 1983:7). Compare the MRN and Bara forms below.

$\begin{array}{lll}\begin{array}{ll}\text { English } \\ \text { 'lord, patron, owner' }\end{array} & \begin{array}{l}\text { MRN } \\ \text { tùmpu }\end{array} & \begin{array}{l}\text { Bara } \\ \text { tùpu }\end{array} \\ \text { 'woman' } & \text { ampèla } & \text { apèla } \\ \text { 'insult, malediction' } & \text { ùmpa } & \text { ùpa } \\ \text { 'destiny' } & \text { vìntană } & \text { vìta } \\ \text { 'story, tale' } & \text { tantàra } & \text { tàtara } \\ \text { 'child-in-law' } & \text { vinàntu } & \text { vinàtu } \\ \text { 'stench' } & \text { hàntsină } & \text { hàtsi } \\ \text { 'plug, cork' } & \text { tsèntsină } & \text { tsètsi }\end{array}$

This reduction is also reflected in traditional texts written in the Sorabe script (Ferrand 1904; Dahl 1983:7); for example, mainty 'black' (Ferrand 1904:86), untsinàva 'servant' (Ferrand 1904:93, 97), and falan 'tàya 'palm of hand'41 (Ferrand 1904:89), which in Sorabe are spelled mayti, utsinawa, and falatana, respectively. These texts also represent a southeastern MLG dialect, as they are written in Old Taimoro MLG.

In this context, it is also worth noting that Mayotte is closer to Madagascar than the other three main islands in the Comoros, not only in geographical terms but also in terms of contacts throughout its history (Allibert 1984, ch. 5). Possibly one-third of the population in

39. Gueunier (2003) points out that while Makhuwa had lexical influence in some regional varieties of MLG, it left hardly any trace on the standard language. This is not unexpected considering its sociolinguistic status. However, it does not exclude a possible Makhuwa influence on the phonology of MLG, including its standard variety.

40. One should also add *-nc- clusters to this series (see Nurse and Hinnebusch 1993:159-62).

41. Most likely $<*$ fala-n-tana (with a genitive marker $-n$-). 
Mayotte currently speaks one of two local varieties of MLG (Gueunier 1986:1, including fin. 1). To summarize, there is a clear context for a more direct historical link with Shimaore, and from the vantage point of MLG dialects in general, there are clearly more similarities in the way Shimaore and MLG have treated the clusters in question than suggested by Wolff.

6. REFLEXES OF PAN INITIAL *s (WOLFF'S *c). Wolff claims that, in MLG, PAN/PMP *s (which is *c in his protophonological system) became $s$ in initial position, and $\emptyset$ intervocalically. In roots with an original ${ }^{\mathrm{s} V s V C}$ structure, the *s at the onset of each syllable is maintained as $s$.

However, Dahl (1951:42) demonstrated that of the many instances of MLG s reflecting PMP *s in initial and intervocalic position, a large number are clearly borrowed. He also showed that MLG instances reflecting $\varnothing$ for PMP *s (and MNY instances with a corresponding $h$ ) do have regular inherited reflexes in their general phonological makeup. Furthermore, he made the valid point that in their homeland, MLG and MNY were surrounded by languages that had maintained *s as $s$. The change from *s to MLG $\emptyset$ and MNY $h$, therefore, seems to have been a regular one, and in cases where these languages show an $s$ $(<\mathrm{PMP} * \mathrm{~s})$, this is most likely the result of borrowing from neighboring languages or from Malay. Exceptions to this, according to Dahl, were roots of an original *sVsVC structure and the numerals MLG, MNY isa 'one' ( $<$ PMP *isa) and MRN sivy, MNY suei 'nine' (<PMP *siwa).

It is also clear that, at some stage in MNY history, $s$ must have felt like a foreign sound: note hypercorrections from $h$ to $s$ in MAL loanwords like tarimakasis 'thank you' ( $<$ MAL torima kasih), samalis 'to slaughter' ( $<$ MAL sambalih), wisis 'calf, lower leg from knee to sole' ( $<$ MAL batih), labis 'more' ( $<$ MAL labih), and kapusunan 'to risk misfortune for failing to fulfill a necessary condition before undertaking something' $(<$ Banjar MAL kapuhunan; Rubay et al. 1997).

Wolff adduces nine etymologies to show that initial PAN/PMP *s is reflected as $s$ or $t s$ in MLG. Two of these reflect an original *sVsVC structure and would therefore fit into the first category of exceptions accepted by Dahl. The etymologies in question are *se(y)sen $(<*$ cen 'stopped up') > MRN tsèntsină 'stopper, cork' and *susuł 'stack up' > MRN sùsună 'folded, double layer' (the latter could also be borrowed from MAL; compare MAL susun 'piled up, position on one another').

A third proposed etymology, *sel(e)sel > nènină 'regret', is probably also meant to fit into this category, but it is a false one. Wolff's explanation that it has "nasalized alternants" of *s is awkward enough as it is. But it also appears that the second $n$ derives from an early MLG velar nasal, not an alveolar one; cf. dialectal forms like SSK nène, Bara nèni, Comorian MLG (Kibosy Kimaore dialect) nènini 'regret, remorse'.

PMP *siwa 'nine' > MRN siff (sic for sivi) is a numeral and fits into Dahl's second category of exceptions.

Two etymologies have initial $t$, which Wolff explains as the result of strengthening of $s$ after a nasal or a stem-final consonant. They are *sudup 'enter with some force' $>$ MRN tsurùf-akă (sic for tsurùfukă in Richardson) 'rush in without permission', and *suluq 'torch'> vua-tsùlu 'burnt'. However, the first of these is faulty because the protoform does not match the supposed MLG reflex. MLG has neither a root *tsuruf- not a suffix *-akă, 
and there is no way a supposed tsuruf-akă can be explained as a reflex of *sudup-an, as Wolff does. Richardson only gives tsurùfukă, which he analyzes as an original *tsufukă with infix *-ur-. Whatever the proposed analysis, the historical relation between *sudup and tsuruf-akă or tsurìfukă is spurious. As to vua-tsùlu, prefixation of vua- never involves strengthening or the insertion of *n at the morpheme boundary between this prefix and the following root: this is clear in examples like vua-suràtr-o 'to be written' (Malzac 1960:54), vua-vali-ko 'answered by me', vua-lazà-ku 'said by me' (Malzac 1960:58). In SSK, vìa- never became attached to the following root. ${ }^{42}$

One etymology has no power of argument because it neither verifies nor falsifies the existence of initial *s. PAN *isenit 'stinger' yielded fanènitră 'wasp', an original derivation that became lexicalized in modern MLG. According to Wolff, the first $n$ is evidence for a historical *s that was lost in the process of prefixing *faN- $(<\mathrm{PAN} * \mathrm{paN}-)$ to *sènitră; however, the derivation may just as well reflect an earlier *paN- + *ènitră, as the outcome yields fanènitră in both cases.

An eighth etymology is PAN *cen 'stopped up' > MRN èsină 'breathe hard'. The latter acquired a prothetic $e$-. Intervocalic *s was usually lost, but $\operatorname{Wolff}(2010: 464, \mathrm{fn} .31)$ argues that in MLG, the change from intervocalic *s to $\emptyset$ had already ceased to be productive when *cen acquired this $e$-. The implied rule order is ad hoc and made to fit a rather contrived etymology in which an intervocalic $\mathrm{s}$ was historically supposedly word-initial.

The last etymology Wolff adduces as evidence is *sapuh > sàfu 'pass over lightly'. This is a straightforward derivation, except for the fact that there is no way of telling whether sàfu is inherited or borrowed. It might just as well reflect MAL sapu.

Finally, there is a tenth case allegedly exhibiting initial $s$ - for *s-, although Wolff does not treat it together with the other etymologies as reflexes of PAN or PMP *s: *simpan 'veering off' > sàmpană 'branch (of road, river), embankment' (Wolff 2010:459). Wolff considers the irregular $a$ in this form as the result of contamination with fàmpană 'precipice'. A relation between sàmpană and *simpan through inheritance is suspect at best. Borrowing from $\mathrm{Ngaju}^{43}$ may be involved (compare Ngaju simpay 'veer' and sampay 'sprouting branches of a tree').

Weighing all this up, if we accept Dahl's conclusion that PAN (initial and intervocalic) *s was lost except in numerals and words with a *sVsVC structure, none of Wolff's MLG examples appear to provide serious counterevidence: nènină and tsurùf-akă/tsurùfukă do not reflect their supposed protoforms, fanènitră has no power of argument, vua-tsùlu does not reflect *s, and sùsună, tsèntsină, and sìvi belong to categories of acknowledged exceptions. The two remaining examples cannot be discarded offhand, but the derivation of èsină from *ceN is contrived at best, and sàfu could just as well be a Malay loanword.

Note, incidentally, that in one case, the change from *s to $h$ also appears to have happened in a word with an original *sVsVC structure: PMP *səpsəp 'to suck' became MNY hehep (but it did retain *s in MRN sèsitră 'to smoke hemp'; see 2.3). Although the

42. In SSK, vìa indicates that the act expressed by the following verb was 'successful' or 'perfect, well-done', as in vìa zày vulanenàu zày (perfect REL say-2SG.GEN REL) 'what you say is true' (Dahl 1951:214-15).

43. An important language spoken in various dialects along the western reaches of the Barito River in Central Kalimantan (Indonesian Borneo). The West Barito languages have exercised influence on the SEB languages (including, so it seems, on MLG), but the extent of this influence remains to be investigated. 
weakening of *s is a feature of both MNY and MLG, an example like this shows that this change was operating in each of these languages separately, and not (or not only) in the language immediately ancestral to both.

\section{CONTACT-INDUCED CHANGE}

7.1 THE HISTORICAL CONTEXT. Prehistoric contacts between Africa and Southeast Asia are ancient and complex, and it will be helpful to give a short overview of some recent discoveries that are pertinent to the settlement history of Madagascar.

An important realization is that the first contacts between Africa and Southeast Asia are much older than this settlement history. The transfer of edible plants, diseases, and various technologies can be dated back to perhaps three centuries BP; on the other hand, the migrations of SEB speakers probably took place as late as the seventh century $\mathrm{AD}$, and their actual settlement of Madagascar seems to have happened about a century later. The Malagasy migrations from Southeast Asia and the settlement of Madagascar are thus no more than a late moment in the long history of contacts between Africa and Southeast Asia. As argued elsewhere (Adelaar 1989, 1995a) and supported by Wolff (2010), it is also likely that SEB speakers had a subordinate role in their own migrations (as ships' crew?), and that Malays (and possibly Javanese) were in control of the navigation routes to East Africa. Indications of this are the hegemonic role of Malays in insular Southeast Asia and their distinct maritime skills during most of the first millennium $\mathrm{AD}$ in correlation with the absence of a maritime orientation of SEB speakers in Borneo and, to a lesser extent, in Madagascar. It is also reflected in the large number of MAL loanwords in MLG, many of which belong to the domain of maritime life and shipping technology.

Another important point to make is that the present integration and evaluation of multidisciplinary research results has led to a growing awareness that Madagascar must have been settled by SEB speakers from the African mainland, rather than directly from Southeast Asia. This is an old idea first launched by the French historian Hubert Deschamps (1960), but it has obtained new momentum since the recent findings of Hurles et al. (2005) and other human geneticists. Two important insights obtained from this research are that, in terms of Austronesian ancestry, the data confirm an origin from Borneo rather than from any other part of the Austronesian world, and that the Malagasy population carries both Austronesian as well as Bantu genes, which were passed on via both the Y-chromosome and mitochondrial DNA line. This suggests that the early SEB migrants had women among them, and that the first settlers in Madagascar already constituted a mixed Austronesian-Bantu population. These insights are in line with archaeological research in the last two decades. They are also in line with the linguistic record. On the one hand, they provide an explanation for the linguistic homogeneity of Madagascar, which basically has one native language, the dialects of which are not very divergent and in general mutually understandable. On the other hand, they also explain the fact that in MLG, Bantu terms for basic domestic plants and animals are more prominent and have kept their meanings much more faithfully than SEB ones. The latter have often lost their original meaning or are used in limited contexts (Blench 2008, 2010). Finally, they provide a partial explanation of the problem of the Malagasy lack of collective memory of a Southeast Asian homeland. Pro- 
vided their collective memory is preoccupied with such issues at all, it is bound to be with a homeland where they stayed immediately before they moved to Madagascar, not one in a more distant past. ${ }^{44}$ For some critical notes on the theory of an "anteroom" period on the African mainland, see Beaujard (2011).

Finally, while this scenario leaves little room for the possibility of an earlier Bantu population in Madagascar, recent palaeozoogeographical research indicates that Madagascar was already inhabited by humans before the arrival of the mixed AustronesianBantu population mentioned above. Blench gives an overview of the evidence, which consists of "human-modified bones of extinct animals, the appearance of pollen of the introduced Cannabis humulus, sudden increases in microscopic carbon particles above background values," "increases in ruderal pollen," the extinction of large animals most probably due to habitat destruction (fires) by humans, and the dramatic decrease of endemic animals correlating with a significant increase in rats and mice (Blench 2007). The notion of a previous population is also present in oral literature in Madagascar.

Burney et al. (2004:25) have carbon-dated the earliest human presence at ca. 2300 BP. Blench concludes from this date that the inhabitants in question cannot have been Bantu speakers, as the latter had not yet arrived in coastal East Africa at that time. He offers some hypotheses as to who these early inhabitants might have been, but it is fair to say that their ethnic affiliations are impossible to determine on the basis of our current knowledge.

\subsection{AFRICAN LANGUAGES THAT MAY HAVE BEEN IN CONTACT}

WITH MALAGASY. Coastal East Africa is linguistically rather variegated, and there have been many migrations and acculturation processes in the last two millennia in this part of the world. In the present discussion, it is therefore necessary to make an inventory of the various African influences that may have affected post-migratory MLG. African languages that may have left their mark on MLG can be categorized as follows.

7.2.1 Early Bantu. Dahl (1954) made a distinction between (recent) Sabaki vocabulary and some older (lexical and grammatical) elements, some of which do not appear in modern Sabaki languages. For instance, MLG words like ùndri 'sheep' and akùndru 'banana' are obviously Bantu but cannot be traced to Kiswahili or any of the Comorian languages. This induced Dahl to introduce his theory of a Bantu substratum that, in his view, represented an ancient form of Comorian. He ascribed the fact that modern Comorian languages do not exhibit all the manifestations of it to recent loss. Simon (1988) also distinguishes two strands of Bantu influence, an older, non-Sabaki strand, and a more recent Kiswahili one. However, Nurse (1988) has doubts about the non-Sabaki nature of Simon's older Bantu evidence. Nevertheless, at the present stage of our knowledge, we should not exclude any possibility, until we have a much deeper insight into the nature of Bantu influence in general.

7.2.2 Comorian languages. These constitute a clear category. Along with the phonological developments that MLG and the Comorian languages have in common, MLG and Comorian have exercised a lexical influence on one another that is clearly identifiable, at least in some cases. As already indicated above, the relationship may not only involve

$\overline{44 .}$ A point also made by Pierre Simon (1988:323-24), although he favors the Comoros as a possible homeland. 
mutual borrowing: theoretically, it is possible that MLG and Comorian languages owe some of their common features to influence from a yet unknown third language.

7.2.3 Kiswahili. Kiswahili has been the main lingua franca and trade language in coastal East Africa for many centuries. It was also a hegemonic language and court language in the Comoros in the past, and the main vehicle for the spread of Islam. This is all clearly reflected in standard MLG, which owes many cultural terms to Kiswahili and obtained much of its Arabic vocabulary through this language (Adelaar 2009b). While clearly present in all varieties of Malagasy, ${ }^{45}$ it is even more prominently so in the dialects of Northwest Madagascar.

7.2.4 Makhuwa. As discussed above, in the past this used to be the first language of many slaves and a lingua franca among slaves in general in Madagascar. While apparently not an important source of lexical borrowing in standard MLG, its possible influence on MLG varieties in general remains a worthwhile object of study.

7.2.5 Cushitic languages. There still are Cushitic languages in East Africa. Before the advent of Bantu languages in this part of the world (ca. second century AD), Cushitic languages were most likely more prominent (and possibly more numerous) than they are today. They may have had a role in the historical development of MLG. At this point there is little to say about this possibility, as it has never been investigated, and given the likelihood that possible donor languages might have been wiped out. However, in theory, Cushitic influence on MLG cannot be ruled out.

7.2.6 A non-Bantu pre-Austronesian language in Madagascar. If there had been a pre-Austronesian population in Madagascar (see 7.1), their language(s) would probably have left some traces in Malagasy. These traces would be anything from a few lexical elements to a substratum. As discussed earlier, we can only guess at the genetic affiliation of such a hypothetical language, and we can say even less about the nature of its influence than we can in the case of Cushitic. Nevertheless, in both this case and the case of Cushitic, we cannot permit ourselves to lose sight of the possibility such influence existed. MLG and Comorian languages have many phonological features in common, but some of these are not typically Sabaki, such as the development of $t r$, the fricativization of stops, and the spirantization of semivowels. It would be careless to explain these and other non-Austronesian features in MLG right away as due to Comorian influence, because they can theoretically have originated in one of the following ways:

- Comorian influence on MLG.

- A spontaneous development in MLG, which was subsequently borrowed into Comorian.

- A spontaneous development that took place independently in both MLG and Comorian.

- Influence from a lost language that was spoken previously in Madagascar and/or the Comoros and left its traces in the present-day languages in the region.

7.2.7 Summary. Outlining six possible sources of African influence is an easy task in comparison to establishing which of them was the exact source of any given borrowed element. They lack categorial specificity and give the impression of overlap. For

$\overline{45 . ~ N o t e, ~ h o w e v e r, ~ t h a t ~ t h e ~ A r a b i c ~ l o a n w o r d s ~ i n ~ T a i m o r o ~ M L G ~(s o u t h e a s t e r n ~ M a d a g a s c a r) ~ a r e ~}$ also due to a Malay influence that predates the influence of Kiswahili (Adelaar 2009). 
instance, many Sabaki Bantu loanwords do not provide a clue as to whether they are specifically Comorian or Kiswahili. Some other Bantu loanwords cannot even be traced to Sabaki, or any other Bantu language in particular; they just seem generically East Bantu. Some loanwords must be Comorian but can only have been borrowed before the latter changed their nominal *ki- prefix to $s h(i)$ - or $(h) i-.^{46}$ There is obviously also no reliable way to identify influence from Cushitic languages or from a lost language that must have been spoken in Madagascar before the arrival of speakers of PMLG, let alone distinguish between the two. (For all we know, this lost language may also have been Cushitic.) This is clearly a research area where an experienced linguist working on comparative Bantu will be able to make more progress than an Austronesianist making educated guesses like the present author.

7.3 THE NATURE OF BANTU INFLUENCE ON MALAGASY. Wolff argues that Bantu influence played a minor role in the phonological history of MLG. He rejects Dahl's theory that there is a Bantu substratum in the language. We should distinguish here between a Bantu substratum, and Bantu historical influence.

Wolff is right in contesting the notion of a Bantu substratum in the sense of influence from a previous language spoken by ancestors of present-day mother tongue speakers of MLG before they shifted to MLG. Dahl's notion of a substratum flowed from his belief that Madagascar had an early population speaking a Bantu language, and more specifically an early form of Comorian, before the arrival of speakers of PMLG. As discussed above, recent research has made it reasonably certain that there were no Bantu speakers in Madagascar before the arrival of Austronesians.

It also makes sense - all things being equal — to dismiss the substantial number of Bantu loanwords in MLG as indicative of a substratum, even if some of these loanwords have penetrated the language's core vocabulary.

However, the rejection of a Bantu substratum should not lead to a denial of the substantial impact that Bantu languages had on MLG in general. According to Wolff (2010:454-455), Dahl's evidence for extensive Bantu influence is threefold and consists of (i) the adoption of loanwords, some of which belong to basic vocabulary, (ii) the development of open syllables, and (iii) the development of continuants from stops. For some reason, Wolff fails to mention that Dahl's evidence also includes a fourth category, Bantu influence on MLG morphology (Dahl 1988:120-25). This is not an easy one to overlook, as it includes, in Dahl's account, the development of a tense system and the adoption of an inanimate noun prefix $k i$ - (see below for a detailed account).

Wolff (2010:449-50) argues that "Austronesian settlement may well have begun in East Africa or on the Comoros, but there is no evidence for it. The extent of Bantu influence on MLG vocabulary indicates intimate contact, but does not necessarily imply Malagasy settlement in Bantu areas. This influence could be explained by slavery and intermarriage (or both), as well. Africans who came to Madagascar over the years mainly

46. For instance, Proto-Sabaki *kilatu 'shoe, sandal' became MrN kiràru, Kiswahili kiatu, Shingazidja ilatru, and Shindzuani shilarù; while there is no ground for tracing MLG kiràru to Kiswahili, it could have been borrowed from Shindzuani, provided that the borrowing happened before *ki became $s h(i)$-, and allowing for the regular regressive assimilation from *1 to $r$ in SEB languages (compare PMP *zalan 'road' > *ralan > MRN làlană; PMP *ludaq 'vomit' $>$ *lura $>$ MRN rùra). 
integrated and intermarried with Austronesians." This is a reflection on ideas about Austronesian settlement presented in Adelaar (2009a). However, the latter is not a detailed treatment of the matter but basically a summary of recent findings and their interpretations, while providing references to more detailed literature. Wolff disagrees with some of these interpretations, but has not taken note of the references in question in order to appreciate the context in which they are proposed. His own conclusions are impressionistic and rather independent from ongoing multidisciplinary discussions on the issue. "The number and character of loanwords from Bantu present a scenario of close contact, and this jibes with the genetic make-up of the [Malagasy] population, which evinces a combination of Asian and Bantu features. The picture is one of a Bantu population that lived in [Malagasy] communities and integrated into them. It is totally possible and in fact likely that Bantu-speaking care-givers raised children in some of the [Malagasy] communities. Bantu speakers were numerous and influential enough to have supplied an important amount and quality of vocabulary and to have influenced [MLG] phonology in ways described above" (Wolff 2010:456). The idea that caregivers of children may have been responsible for the changes in MLG is a bit of a cliché that does not bring us any closer to understanding MLG linguistic history. While the role of nannies may have had its value in understanding creolization processes in European colonial settings, it has hardly any explanatory force with regard to the settlement of Madagascar, which took place under very different cultural conditions.

There were of course, many slaves brought to Madagascar. And there are, of course, certain areas, such the west coast of Madagascar, where their presence was more prominent than in others and where they have left more abundant phenotypical and cultural traces. Important as they may be, these factors belong to a more recent part of the island's history. They do not account for more imperative factors applying to the population of Madagascar as a whole, such as the common gene pool of the Malagasy, the archaeological record, and the comparative linguistic evidence pointed out in 7.1.

\subsection{INVENTORY OF CONTACT-INDUCED INFLUENCE FROM} BANTU LANGUAGES IN MALAGASY. It is hard to avoid the impression that Bantu languages must have had a thorough and pervasive effect on the development of MLG, given the various manifestations of their influence on its grammar, lexicon, and phonology. These manifestations include the following ones:

(i-iii) The development of final open syllables, the spirantization and affricativization of stops and semivowels, and cluster reduction, which were discussed above. These phenomena should at least be partly attributed to Bantu influence.

(iv) The existence of many loanwords, including basic vocabulary items, such as màsu 'eye' < Kiswahili macho, Shindzuani, Shingazidja matso 'eyes', and akuhu 'chicken' < Kiswahili khuku, Shindzuani, Shingazidja $\eta$-kuhu, Shimaore akuhu (Dahl 1988).

(v) Influence on the verb system, which resulted, among other things, in the development of a full-fledged tense system (Dahl 1988). Future tense is formed with the substitution of initial $h$ - for $m$ - in prefixes beginning with $m$-, the prefixation of $h$ - to verb forms with an initial vowel, and with the particle $h u$ preceding verb forms with an initial consonant. Past tense is formed with the substitution of initial $n$ - for $m$ - in prefixes beginning 
with $m$-, the prefixation of $n$ - to verb forms with an initial vowel, and with $\emptyset$ (or, sometimes, a particle $n u$ ) preceding verb forms with an initial consonant ${ }^{47}{ }^{4}$ Examples:

(26) M-angàlatră Pàuli.

'Paul steals.'

H-angàlatră Pàuli.

'Paul will steal.'

$\mathrm{N}$-angàlatră Pàuli.

'Paul stole.'

cf. hàlatră 'stealing'; ( $\mathrm{h} / \mathrm{m} / \mathrm{n} /) \mathrm{aN}$ - 'actor-oriented prefix'

(27)

Umè-nă àzi ni vùla. 'Money is given to her.'

H-umè-nă àzi ni vùla. 'Money will be given to her.'

N-umè-nă àzi ni vùla. 'Money was given to her.'

cf. ùme 'giving'; -ină, -ană 'undergoer-oriented suffix'; àzi '3SG.OBJ'; ni 'DEF.ART; vùla 'money'

(28) Tùnga izàu ìzi. 'He arrives today.'

Hu tùnga rahampìtsu ìzi. 'He'll arrive tomorrow.'

Tùnga umàli ìzi. 'He arrived yesterday.'

cf. tùnga 'to arrive'; izàu 'today'; rahampitsu 'tomorrow'; umàli 'yesterday';8 hu 'FUT'; izi '3SG.SUBJ'

(vi) Influence on noun morphology, shown in the adoption of the synonymous prefixes $k i$ - and tsi- These reflect the Class 7 noun prefix $k i$ - and its palatalized variant $c i$ in Bantu languages (Dahl 1988). They form nouns often with a diminutive meaning; for example, MRN trànu 'house' (< MAL danaw 'field hut') vs. ki-tranu-trànu, tsi-tranutrànu 'doll house' (Dahl 1988:120).

(vii) Influence on the deictic system. MLG has many locative adverbs that generally fit into a scale marking them for relative distance. However, one adverb does not fit into this scale: ào 'there inside' refers to an unspecified distance inside a confined space. This is in line with Kiswahili humu and $m l e$, which also refer to a confined space (although they are more specific than MLG ào in terms of relative distance) (Wilson 2009:28-31, 55). Compare these Kiswahili deictic terms in the following arrangement of locative adverbs:

(29)
Definite space: hapa 'here'
pale 'there'
Indefinite space:
Confined space
huku 'here about'
kule 'there about'
humu 'here inside'
mle 'there inside'

The category of 'inside space' that MLG has in common with Kiswahili is neither inherited from PAN nor usual in Austronesian languages. It could be due to Bantu influence on MLG.

(viii) Finally, the altered overall stress pattern of MLG could also be seen as an indication of a shared phonological history with Comorian languages. ${ }^{49}$ As discussed earlier in this paper (see 2.3), modern MLG dialects have traded the original PSEB antepenultimate and nondistinctive word stress pattern for one that is distinctive and may fall on the antepenultimate, penultimate, or last syllable. The place of stress is also unpredictable in Comorian languages. ${ }^{50}$ However, this historically transparent change is best explained as a by-product of the overall phonological changes in MLG (especially vowel contraction

47. The forms $h$ - and $h u$ most probably reflect Sabaki *ku, which is an infinitive marker, among other things; $n$ - is cognate with the MNY undergoer prefix $n a$-, and both reflect the PAN perfective aspect prefix *ni- (Dahl 1988; Adelaar 2010).

48. MRN um/àli 'yesterday' is cognate with MNY am/alem (with antepenultimate neutralization of *u to $a$ ) 'to spend the night' (Dahl 1951:324); both reflect PSEB *um-alem 'to spend the night'.

49. I am indebted to John Hajek for alerting me to the importance of stress pattern changes in MLG as an indication of language contact. 
and the addition of paragogic vowels), although the effect of lexical borrowing may also have played a role. ${ }^{51}$ Although this change in overall stress pattern has brought about a radical change in MLG prosody, it is only indirectly due to contact with Sabaki languages.

8. PROBLEMATIC ETYMOLOGIES. Among the many etymologies presented by Wolff in support of his analysis, a substantial number have to be rejected. Other etymologies are inaccurate because of a lax application of the regular sound correspondence rules, or a failure to distinguish between inherited and borrowed vocabulary. I have already discussed some of these in the previous pages. Other ones follow below.

(30) PAN *pukuh > bòko 'pompon'.

According to Wolff (2010:462), this development is "contaminated in PMP or earlier by *bukul 'knobshaped', cf. T[agalo]g búkol 'boil, tumor', C[e]b[uano] buykul 'bulging bones in joints'." Neither of the consonants in boko faithfully reflect their alleged counterparts in *pukuh: as a rule, $* \mathrm{p}>f$ and ${ }^{*} \mathrm{k}>h$.

(31) PMP * pudul $>$ mùndru 'blunt'.

None of the consonants in mùndru corresponds regularly to those in *pudul $\left({ }^{*} \mathrm{p}>f ;{ }^{*} \mathrm{~d}>r\right.$, and the addition of a nasal in -ndr- is unusual; $*-1>-n \breve{a})$.

(32) PMP *binkuk 'crooked' > bìngu 'bow-legged'.

None of the consonant correspondences is regular: as a rule, ${ }^{*} \mathrm{~b}->\mathrm{v},{ }_{-}$ $\mathrm{\eta \textrm {k }}->k,{ }^{*}-\mathrm{k}>-\mathrm{k} a$.

(33) PMP *pisaw $>$ mìsu 'knife'.

Wolff (2010:452) notes that misu is "not inherited from PMP," which begs the question of where it comes from, and why it is presented as a reflex of *pisaw. As a reflex of the latter, both consonants are problematic (PMP *p- $\left.>f_{-}, *_{-s-}>\emptyset\right)$; moreover, the vowels are unstable, considering the presence of the variant forms mèsu and mèsa. The word also closely resembles SSK kisu, which must be borrowed from Kiswahili (compare Kiswahili kì-su 'knife'). According to Beaujard (2011:175), it is a Dutch loanword (compare Dutch mes), which is not impossible since the Dutch had a presence in Madagascar in the seventeenth and eighteenth centuries. However, a more likely origin is the plural form misu of $m s u$, an archaic Kiswahili term for 'knife'; cf. also modern Kiswahili msu/meno 'saw', which historically consists of $m s u$ - 'knife' + meno 'teeth' (Martin Walsh, pers. comm.).

50. Compare the following Shindzuani disyllables: nyumbà 'house', dàgo 'house', gìdzo 'market'. In Shindzuani, the issue is complicated further by the unpredictability of stress shift in suffixed words: compare penultimate stress in dagò-ni 'in the house' to last syllable stress in gidzo-ni 'in the market' (Philippson 1993:253-54). This is not the case in MLG, which agrees with MNY and many other Austronesian languages in shifting stress regularly to the following syllable through suffixation, except if the root is monosyllabic (in which case no shift occurs). Note also that distinctive stress is not typical for all Sabaki languages: it does not apply to Kiswahili, which has regular penultimate word stress.

51. However, I would speculate that, insofar as lexical borrowing may have put a strain on the original SEB stress pattern of MLG, this would more likely be the result of Arabic and European loanwords than of Sabaki ones. 
(34) PMP *dabuk 'pound' > dàbukă 'beat, stump'.

This derivation is very doubtful on account of irregular $d$ and $b$.

(35) PAN *disədis 'slice' > dìdi 'cut'.

Again, $d$ is irregular, as MRN $d i$ sequences reflect earlier *li; compare SSK lili 'to cut' < PMLG *lili.

(36) PAN *kaSiw > hàzu 'wood, tree' (Wolff 2010:463).

This protoform allegedly became *kayu in an intermediate stage. However, as already discussed in 2.3, Mahdi (1988:150) demonstrated that PAN *-y- was lost in SEB languages, and that the regular MNY reflex of *kaSiw (and *kayu) is ka-kau 'tree'.

(37) PAN *buRuk 'rotten' > vùzu 'lazy'.

Loss of *-k is irregular, and by Wolff's own account (2010:467) the forms are "probably unconnected."

(38) PMP *kima 'giant clam' > hìma 'k.o. shell'.

The final vowel is irregular $\left({ }^{*}-\mathrm{a}>\mathrm{MLG}-i\right)$; as a maritime term, it must be borrowed from MAL.

(39) PMP *bikas > ma-vìă 'strong, athletic'.

These forms are phonologically incompatible: *bikac would normally yield a reflex *viha, and the PMLG etymon of $m a-v i k a$ is *wi(i)k; the latter is supported by the suffixed derivation ha-vih-ană 'energy' and by SSK ma-vike 'agile, quick'.

(40) PAN *apu 'grandparent; ancestor' > àfi, z/àfi 'grandchild' (Wolff 2010:459).

Wolff tentatively explains MRN $-i$ as the result of the weakening of *-u to [ə] in vocative usage, with subsequent change from [ə] to $-i$. However, there is no precedent for such weakening in MLG history, and the explanation is ad hoc. ${ }^{52}$

(41) PAN *ma-iRaq 'red' > mèna.

According to Wolff (2010:459-67), *ma-iRaq first became *maia, and later on mèna through the addition of an unspecified *-nă. It is neither clear why this *-nă should have been added nor what it stands for. MLG does not have a suffix -nă. If it is meant to be one of Wolff's cases of erroneous consonant addition (cf. 2.1), it does not really qualify, as in Wolff's own account these concern the wrong choice made in the reintroduction of a final consonant, not the introduction of a consonant where there had never been any in the first place.

(42) PAN *luSəq 'tears' > jùi 'tears; crying weeping'.

The default term for 'tears' is rànu màsu (lit. 'eye water'); jùi is an unusual term found only in Richardson (1885). Phonologically, *luSeq and jui do not correspond at all: the expected reflex of

52. The form (z)àfi has a SSK cognate àfe. Although the semantic relation is not obvious, from a formal perspective it must be related to early Malayic *apa(?) 'one's own father', which is originally borrowed from Dravidian and has corresponding forms in Sundanese, Madurese, Soboyo, and many Malayic varieties. *apa(?) occurs in present-day Standard Malay and Indonesian as $b / a p a / k$. The latter has fossilized affixes *b(a)- 'to function or behave as' and *-k 'vocative'. These affixes are also found in several other Malay kinship terms (Adelaar 1992:104 fn. 149, 150). 
*luSəq would be *lu, and $j$ does not reflect any of the phonemes of PAN, PMP, or PSEB if it occurs in initial position. ${ }^{53}$

(43) PAN *waRəd > vàhy 'liana'.

This is another reflex that, according to Wolff, fails to exhibit an expected final consonant (-tră). However, it also has irregular $h$ for *R (which stands for a velar fricative [y]). On the other hand, vàhy has an unproblematic MNY cognate wakay 'plant climbing along the stems of other trees' (Rubay et al. 1997). Obviously, vàhy and wakay do not reflect *waRed at all but must have developed from a common PSEB protoform *wakay.

(44) PMP *sampay 'arrive' > àmpi 'sufficient and complete' (Wolff 2010:464). $\mathrm{PMP} *$ cahebay > mi-sàmpi 'hang', sampàz-ană 'clothesline, place to hang things' (Wolff 2010:470).

Here, Wolff fails to notice that both sàmpi and àmpi are loanwords and ultimately derive from the same Malay word. The meaning 'to hang' is obviously the old default meaning of MAL sampay, and it is still indicated as a basic meaning in Wilkinson. Other meanings, such as 'arrive' and 'complete' or 'sufficient', are due to later shifts. MLG sàmpi and sampàz-ană clearly reflect the basic meaning of sampay, and àmpi, the derived meaning. The fact that àmpi 'sufficient and complete' lost initial $s$ - while sàmpi 'hang' did not simply indicates that the former was used more frequently and became more adapted to the erstwhile MLG word structure (which had no $s$ ) than sàmpi. A somewhat parallel situation is found in Malay, where sampay in the sense of 'to hang' has become obsolete, and the modern word has come to mean 'to arrive; to reach', 'sufficient', and 'until'.

(45) PMP *paya > fànza 'swamp' (Wolff 2010:454, 461).

Somewhat reluctantly, Wolff concludes that fanza must be borrowed rather than inherited on account of the unusual nasal accretion in it. However, the maintenance of *-a is also irregular (PMP *-a as a rule becomes $-i$ ), reinforcing a borrowing hypothesis.

Finally, Wolff rejects a South Sulawesi origin of MRN vàdi 'spouse' (Adelaar 1995), because "it looks inherited from PMP, ... it is widely attested over the range of MalayoPolynesian languages, and there is nothing in the semantics of MLG vàdi to indicate a close connection with reflexes in S[outh] Sulawesi” (Wolff 2010:462 fn. 29). While cognates of vàdi are widely attested in Austronesian languages, the meaning 'spouse' (or other closely associated meanings) attached to it is much less widely attested. In Adelaar (1995), my reasoning that vàdi must be a South Sulawesi loanword is as follows:

- None of the other SEB languages has a cognate of vàdi with this meaning. What they have instead are reflexes of PAN *sawa 'wife', *bana 'husband', or other words. An exception is the form kabali 'wife' in a Maanyan bible text (Soerat sarita 1938:8). In other words, MLG must have replaced the gender-specific PAN terms for 'spouse'

53. A Bantu source would be more likely but needs further justification; compare Shingazidja tsozi (Shindzuani utsozi), Kiswahili chozi 'tear' (and Proto-Sabaki *ịcozị, Common Bantu *-códị 'tear'). 
(which were inherited in PSEB) with a generic * wali, yielding present-day MRN vàdi and SSK vàli.

- On the contrary, cognates of vàdi with meanings associated with 'spouse' do occur in South Sulawesi languages. Compare Makassarese bali 'relation between people belonging to the house of the bride and those belonging to the house of the bridegroom' and pa?-bali-bali-ay 'spouse'. Compare also South Toraja ${ }^{54}$ bali '1. partner, associate, mate, spouse, opponent; 2. reply, retaliate; 3. go against, resist', and si-bali 'to get married' ( $s i$ - being a verbal prefix expressing reciprocality). Mills (1975) reconstructs for Proto-South Sulawesi *bali, which covers the following meaning configuration: '1. side (friend, partner); 2. enemy (oppose); 3. answer (contradict, answer back)'. This form in turn goes back to PAN 1. *baliw/*maliw 'transformation, metamorphosis' and *baliw-an 'change, substitute, repeat'; 2. *baliw 'oppose, opposite part; friend, partner'; 3. *baliw(-an) 'don mourning apparel; mourn for a deceased spouse'; 4. *baliw(-an) 'repay, return in kind; retaliate, take revenge = equalize (a loss or debt)' (Blust 1980:224-28).

- According to Blust, PAN *baliw yielded both MRN vàdi 'partner, husband, wife; a companion, an associate; a mate, one of a set of two (thus the saucer is the vàdi of a cup)' and MRN vàlu 'alteration'. He argues that at a post-PAN stage, *baliw (with the first meaning of 'transformation, metamorphosis') often became metathesized to *baluy, which ultimately resulted in MLG vàlu. Meanwhile, *baliw with the second meaning of 'oppose, opposite part; friend, partner' never underwent this metathesis and resulted in MLG vàdi. However, although not impossible, it is somewhat unusual for a protoform to have several inherited reflexes. Another possibility is that vàlu is inherited, and vàdi borrowed. This would be in agreement with a South Sulawesi origin of vàdi.

9. CONCLUDING REMARKS. In the previous pages, I have demonstrated the overwhelming importance of Bantu influence in MLG, an influence that should be acknowledged and accounted for in all future research regarding MLG linguistic history.

Wolff's approach to Bantu influence is a clear case of throwing out the baby with the bath water. While opposing with some justification Dahl's concept of a Bantu substratum, Wolff downplays Bantu influence in general, only recognizing it in the MLG lexicon. However, a more detailed and step-by-step analysis of the developments that led to the MLG phonological system as it appears to us today shows the undeniable impact of Bantu on postmigratory MLG.

It generally makes sense to view the changes that MLG has undergone in terms of a common contact period involving MLG and Bantu languages, rather than the result of a one-way influence of Bantu languages on MLG. MLG also had some impact on Comorian languages and Kiswahili, in the form of lexical borrowing, but possibly also in the form of grammatical influence. ${ }^{55}$ Furthermore, some of the commonalities shared between MLG and the Comorian languages are innovative in both, which opens the possibility of a third,

54. Nowadays usually called Sa'dan Toraja.

55. See also Blench and Walsh's (n.d.) list of MAL loanwords in Kiswahili, many of which belong to the domains of shipping technology and harbor life. 
yet unidentified, linguistic source. This does not come as a total surprise. After all, postmigratory MLG must have been exposed to a variety of African languages. These included at least Comorian languages and Kiswahili, and they may also have included Makhuwa and another, earlier, Bantu source. Finally, there may have been influences from Cushitic and, hypothetically, from the language of the first inhabitants of Madagascar.

\section{APPENDIX. DATA SOURCES}

\begin{tabular}{|c|c|c|}
\hline LANGUAGE NAME & ABBREVIATION & SOURCE \\
\hline Antaisaka Malagasy & Antaisaka MLG & Deschamps (1936) \\
\hline Banjar Malay & BJRMAL & Abdul Jebar Hapip (2006) \\
\hline Bara Malagasy & Bara MLG & Elli (1988) \\
\hline Comorian in general & & Nurse and Hinnebusch (1993) \\
\hline Javanese & JAV & Pigeaud (1938) \\
\hline Kiswahili & & Wilson (2009) \\
\hline Malagasy (in general) & MLG & \\
\hline Malay & MAL & Wilkinson (1959) \\
\hline Maanyan & MNY & Dahl (1951) \\
\hline Merina & $\mathrm{MRN}$ & $\begin{array}{l}\text { Webber (1853), Richardson (1885), } \\
\text { Abinal and Malzac (1988) }\end{array}$ \\
\hline North Sakalava & NSK & Thomas-Fattier (1982) \\
\hline Old Javanese & OJ & Zoetmulder (1983) \\
\hline $\begin{array}{l}\text { Old Taimoro Malagasy } \\
\text { (Sorabe script) }\end{array}$ & & Ferrand (1904) \\
\hline Proto-Austronesian & PAN & $\begin{array}{l}\text { Blust and Trussel (in progress), Wolff } \\
\text { (2010) }\end{array}$ \\
\hline Proto-Malagasy & PMLG & this article or as indicated \\
\hline Proto-Malayo-Polynesian & PMP & $\begin{array}{l}\text { Blust and Trussel (in progress), Wolff } \\
(2010)\end{array}$ \\
\hline Proto-South East Barito & PSEB & this article or as indicated \\
\hline Sabaki & & Nurse and Hinnebusch (1993) \\
\hline South Betsimisaraka & SBM & Ruud (1955) \\
\hline South East Barito & SEB & Hudson 1967 \\
\hline Shimaore & & $\begin{array}{l}\text { Nurse and Hinnebusch (1993), Rombi } \\
\text { (1983) }\end{array}$ \\
\hline Shindzuani & & Ahmed-Chamanga 1992, 1997 \\
\hline Shingazidja & & Lafon (1991) \\
\hline Old South Betsimisaraka & Old SBM & Flacourt (1658) (also in Ferrand 1905) \\
\hline South Sakalava & SSK & Gueunier (n.d.) \\
\hline Tandroy Malagasy & Tandroy MLG & Rajaonarimanana and Fee (1996) \\
\hline
\end{tabular}

MLG stands for the Malagasy language in general unless it is specified by a preceding dialect name. Note that Betsimisaraka and Sakalava are originally ethnic and geopolitical entities, not linguistic labels. There are North and South Betsimisaraka dialects, and there are also North and South Sakalava dialects. In both instances, the northern and southern dialects appear to be less akin to one another than to other nearby dialects. Note furthermore 
that in the literature, the labels "Betsimisaraka" and "Sakalava" usually refer to SBM and SSK, respectively.

Old SBM data and data in Houtman (1603) are in their original spelling. Other MLG data are also in their original orthography except for the following changes: $o$ is replaced by $u$, paragogic vowels are marked with a breve $(\breve{a}, \breve{e}$, etc.), velar nasals are rendered as $\eta$, and stress is indicated. In Old Taimoro MLG, stress is not indicated, and the Arabic letter waw is transcribed as a $w$, as it is more accurate than Ferrand's $v$. PAN and PMP etyma are in Blust's orthography (Blust and Trussel in progress), with the proviso that if they contain *e, this letter is rendered as $*$, as it stands for a schwa.

\section{REFERENCES}

Abdul Jebar Hapip. 2006. Kamus Banjar Indonesia. Banjarmasin: Pt. Grafika Wangi Kalimantan.

Abinal, Antoine, and Victorin Malzac. 1888. Dictionnaire malgache-français. Paris: Éditions maritimes et d'Outre-mer. (reprinted in 1970).

Adelaar, Alexander. 1989. Malay influence on Malagasy: Linguistic and culture historical inferences. Oceanic Linguistics 28:1-46.

- 1992. Proto-Malayic: The reconstruction of its phonology and parts of its morphology and lexicon. Canberra: Pacific Linguistics.

- 1994. Malay and Javanese loanwords in Malagasy, Tagalog and Siraya (Formosa). Bijdragen tot de Taal-, Land-en Volkenkunde 150(1):49-64.

. 1995a. Asian roots of the Malagasy: A linguistic perspective. Bijdragen tot de Taal-, Land-en Volkenkunde 151(3):325-57.

_. 1995b. L'importance du samihim (Bornéo du Sud) pour l'étymologie malgache. In L'étranger intime. Mélanges offerts à Paul Ottino. Madagascar. Tahiti-Insulinde Monde Swahili - Comores - Réunion, ed. by B. Champion, 47-55. Saint-André (La Réunion): Océan Éditions (Université de la Réunion).

. 2009a. Towards an integrated theory about the Indonesian migrations to Madagascar. In Ancient human migrations: A multidisciplinary approach, ed. by P. N. Peregrine, I. Peiros, and M. Feldman, 149-72. Salt Lake City: University of Utah Press.

- 2009b. Loanwords in Malagasy. In Loanwords in the world's languages: A comparative handbook of lexical borrowing, ed. by Martin Haspelmath and Uri Tadmor, 717-46. Berlin: Mouton de Gruyter.

. 2010. The amalgamation of Malagasy. In A journey through Austronesian and Papuan linguistic and cultural space: Papers in honour of Andrew K. Pawley, ed. by John Bowden, Nikolaus P. Himmelmann, and Malcolm D. Ross, 161-78. Canberra: Pacific Linguistics.

Ahmed-Chamanga, Mohamed. 1992. Lexique comorien (shindzuani-français). Paris: L'Harmattan.

- 1997, Dictionnaire français-comorien. Paris: L'Harmattan.

Allibert, Claude. 1984. Mayotte: Plaque tournante et micrcosme de l'Océan Indien occidental. Paris: Éditions Anthropos.

Beaujard, Philippe. 1998. Dictionnaire malgache-français. Paris: L'Harmattan.

. 2011. The first migrants to Madagascar and their introduction of plants: Linguistic and ethnological evidence. Azania 46(2):169-89.

Blench, Roger. 2007. New palaeozoogeographical evidence for the settlement of Madagascar. Azania 42:69-82. 
2008. The Austronesians in Madagascar and their interaction with the Bantu of the East African coast: Surveying the linguistic evidence for domestic and translocated animals. Studies in Philippine Languages and Cultures 18:18-43.

- 2010. Evidence for Austronesian voyages in the Indian Ocean. In The global origins and development of seafaring, ed. by Atholl Anderson, James H. Barrett, and Katherine V. Boyle, 239-48. McDonald Institute for Archaeological Research Monographs, University of Cambridge. Cambridge: Cambridge University Press.

Blench, Roger, and Martin Walsh. n.d. Indian Ocean maritime prehistory: Evidence from the lexicon.

Blust, Robert. 2009. The Austronesian languages. Canberra: Pacific Linguistics.

. 2011. Dempwolff reinvented: A review of Wolff (2010). Oceanic Linguistics 50:560-79.

Blust, Robert, and Stephen Trussel. In progress. Austronesian comparative dictionary. Available online at www.trussel2.com/acd.

Burney, D. A., L. P. Burney, L. R. Godfrey, W. L. Jungers, S. M. Goodman, H. T. Wright, and A. J. Jull. 2004. A chronology for late prehistoric Madagascar. Journal of Human Evolution 47:25-63.

Dahl, Otto Christian. 1937. Le système phonologique du proto-malgache. Norsk Tidsskrift for Sprogvidenskap 10:189-235.

. 1951. Malgache et Maanyan. Une comparaison linguistique. Avhandlinger utgitt av Instituttet 3, Oslo: Egede Instituttet.

. 1977. La subdivision de la famille barito et la place du malgache. Acta Orientalia (Copenhagen) 38:77-134.

. 1983. Le Sorabe révélant l'évolution du dialecte antemoro. Antananarivo: Trano Printy Loterana (TPFLM).

. 1988. Bantu substratum in Malagasy. Études Océan Indien 9 (Linguistique de Madagascar et des Comores), 91-132.

Dempwolff, Otto. 1937. Vergleichende Lautlehre des Austronesischen Wortschatzes. Band II: Deduktive Anwendung des Urindonesischen auf austronesische Einzelsprachen. 17. Beiheft zur Zeitschrift für Eingeborenen-Sprachen. Berlin: Dietrich Reimer Verlag.

Deschamps, Hubert. 1936. Le dialecte antaisaka (langue malgache). Tananarive: Pitot de la Beaujardière.

Dez, J. 1981. Vocabulaire pour server au déchiffrement des documents arabico malgaches. Paris: Département de Recherches Linguistiques, Université Paris 7. (Unpublished manuscript).

Djantera Kawi, Abdurachman Ismail, and Willem Ranrung. 1984. Struktur bahasa Maanyan. Jakarta: Departemen Pendidikan dan Kebudayaan

Elli, Luigi. 1988. Dizionario Bara-Italiano. Fianarantsona: Ambozontany.

Elkins, Richard E. 1968. Manobo-English dictionary. Oceanic Linguistics Special Publication no. 3. Honolulu: University of Hawai'i Press.

Ferrand, Gabriel. 1904. Un texte arabico-malgache du XVIe siècle. Transcrit, traduit et annoté d'après les mss 7 et 8 de la Bibliothèque Nationale. Paris: Imprimerie Nationale.

. 1905. Dictionnaire de la langue de Madagascar, d'après l'édition 1658 et l'Histoire de la grande Isle Madagascar de 1661. Publications de l'École des Lettres d'Alger, Bulletin de Correspondence Africaine Tome XXXIII. Paris: Ernest Leroux, Éditeur.

Flacourt, Étienne. 1658. Dictionnaire de la langue de Madagascar. Paris: Georges Josse, rue St. Jacques à la Couronne d'Épines.

Gericke, J. F. C., and T. Roorda. 1901. Javaansch-Nederlandsch handwoordenboek (revised and expanded by A. C. Vreede). Amsterdam: Muller. 
Gueunier, Noel J. 1986. Lexique du dialecte malgache de Mayotte. Études Océan Indien 7 (Numero spécial Dico-Langues'O). Paris: Institut National des Langues et Civilisations Orientales.

- 2003 Documents sur la langue makhuwa à Madagascar et aux Comores (fin XIXe-début XXe siècles) avec un lexique du makhuwa de Madagascar et des Comores. Études Océan Indien 35-36:149-223.

_. n.d. Dictionnaire des dialectes malgaches du sud-ouest (fondé sur le Dictionnaire Sakalava-Merina-Français de Victor Denis Mahavere [1925-1926] revu et complété par Noël J. Gueunier). Electronic file.

Houtman van Gouda, Frederick de. 1603. Spraeck ende woord-boeck inde Maleysche ende Madagaskarsche talen met vele Arabische ende Turcsche woorden [...]. Amsterdam: J. E. Cloppenburch.

Hudson, Alfred B. 1967. The Barito isolects of Borneo. Southeast Asia Program (Dept. of Asian Studies), Data Paper no. 68. Ithaca NY: Cornell University Press.

Hurles, Matthew E., Bryan C. Sykes, Mark A. Jobling, and Peter Forster. 2005. The dual origin of the Malagasy in island Southeast Asia and East Africa: Evidence from maternal and paternal lineages. American Journal of Human Genetics 76:894-901.

Kikusawa, Ritsuko. 2006, A Malagasy (Northern Betsimisaraka) text with grammatical notes. Journal of Asian and African Studies 71:5-37.

Lafon, Michel. 1991. Lexique français-comorien (shingazidja). Paris: L'Harmattan.

Mahdi, Waruno. 1988. Morphophonologische Besonderheiten und historische Phonologie des Malagasy. Veröffentlichungen des Seminars für Indonesische und Südseesprachen der Universität Hamburg, Band 20. Berlin: Dietrich Reimer Verlag.

- Forthcoming. Review of J. U. Wolff, Proto-Austronesian phonology with glossary, vols I and II, 2010. To appear in Archipel.

Malzac, R. P. 1960. Grammaire malgache. Paris: Société d'Editions Géographiques, Maritimes et Coloniales.

Mills, Roger F. 1975. Proto-South Sulawesi and Proto-Austronesian phonology. PhD diss., University of Michigan, Ann Arbor. (University Microfilms International, 1978).

Munthe. Ludvig. 1982. La tradition arabico-malgache vue à travers le manuscrit A-6 d'Oslo et d'autres manuscrits disponibles. Antananarivo: Trano Printy Loterana (TPFLM).

Nanang, Yohanes Kalamper, and Moses Usman. 1988. Morfologi dan sintaksis bahasa Bayan. Jakarta: Pusat Pembinaan dan Pengembangan Bahasa, Departemen Pendidikan dan Kebudayaan.

Nurse, Derek. 1988. Review of Pierre Simon, Ny fiteny fahizany. Reconstitution et périodization du malgache ancien jusqu'au XIVè siècle, 1988. Études Océan Indien 10:141-46.

Nurse, Derek, and Thomas J. Hinnebusch, eds. 1993. Swahili and Sabaki. A linguistic history. University of California Publications in Linguistics Volume 121. Berkeley and Los Angeles CA: University of California Press.

Philippson, Gérard. 1993. Tone (and stress) in Sabaki. In Swahili and Sabaki. A linguistic history, ed. by Derek Nurse and Thomas J. Hinnebusch, 248-65. University of California Publications in Linguistics Volume 121. Berkeley and Los Angeles CA: University of California Press.

Pigeaud, Th. G. Th. 1938. Javaans-Nederlands handwoordenboek. Groningen: Wolters Noordhoff. (2nd ed. 1982: Leiden: Royal Institute of Linguistics and Anthropology).

Rajaonarimanana, Narivelo, and Sarah Fee. 1996. Dictionnaire malgache dialectal-français. Dialecte tandroy. Dictionnaires des Langues O', Langues de l'Océan Indien Occidental. Paris: Langues \& Mondes, L'Asiathèque.

Richardson, J. 1885. A new Malagasy-English dictionary. Tananarivo: The London Missionary Society. 
Rombi, Marie-Françoise. 1983. Le shimaore (Ile de Mayotte, Comores). Première approche d'un parler de la langue comorienne. Langues et Cultures Africaines 3. Paris: Société d'Études Linguistiques et Anthropologiques de France.

Rubay, G. S., Adjin Widen, Pagoe Bangel, C. Dj. Bandrang, Apria Dansen, and C. Yus Ngabut. 1997. Kamus Bahasa Ma'anyan. Edisi II. Palangkaraya: Proyek Pembinaan Perpustakaan Umum Dati II (tersebar di enam Kabupaten/Kotamadya Dati II. Tahun Anggaran 1996/1997).

Ruud, Joergen. 1955. Étude grammaticale du dialecte betsimisaraka du sud. Bulletin de l'Académie Malgache 33:33-55.

Simon, Pierre. 1988. Ny fiteny fahizany. Reconstitution et périodization du malgache ancien jusqu'au XIVe siècle. Travaux et documents 5 du CEROI, Paris: Institut des Langues et Civilisations Orientales.

Soerat Sarita hengka Soerat lengan Alatalla [Biblische Geschichten in der Maanjan-Dajaksprache) 1938. Bandjermasin: Bazelsche Zending (Leiden University Library No. 901 F85).

Steinhauer, Hein. 2005. Colonial history and language policy in insular Southeast Asia and Madagascar. In The Austronesian languages of Asia and Madagascar, ed. by Alexander Adelaar and Nikolaus P. Himmelmann, 65-86. Routledge Language Family Series. London: Routledge.

Stokhof, W. A. L., ed. (in cooperation with Alma E. Almanar). 1986. Holle lists: Vocabularies in languages of Indonesia, vol. 8: Kalimantan (Borneo). Canberra: Pacific Linguistics.

Thomas-Fattier, D. 1982. Le dialecte sakalava du Nord-Ouest de Madagascar. Phonologiegrammaire - Lexique. Langues et Civilisations de l'Asie du Sud Est et du Monde Insulindien. Langues, Cultures et Sociétés de l'Océan Indien No 10. Paris: SELAF, Centre de Documentation et de Recherches sur l'Asie du Sud Est et le Monde Insulindien.

van de Velde, Jenneke. 2009. Word order and information structure in Makhuwa Enahara. Netherlands Graduate School of Linguistics Publication No 215. Utrecht: LOT.

van der Tuuk, Herman Neubronner. 1865. Outlines of a grammar of the Malagasy language. Journal of the Royal Asiatic Society of Great Britain and Ireland (New Series) 1:419-46.

Webber, J. 1853. Dictionnaire malgache-français [Malagasy-French dictionary]. Île Bourbon: Établissement Malgache de Notre-Dame de la Ressource.

Wehr, Hans. 1994. A dictionary of modern written Arabic (Arabic-English). 4th ed. (ed. by J. M. Cowan). Ithaca NY: Spoken Language Services, Inc.

Wilkinson, R. J, 1959. A Malay-English dictionary. London: Macmillan.

Wilson, Peter M. 2009. Simplified Swahili (New Edition, 23rd impression). Harlow, UK: Longman.

Wolff, John U. 2010. Proto-Austronesian phonology with glossary, vols I and II. Cornell Southeast Asia Program Publications. Ithaca NY: Cornell University Press.

Zoetmulder, P. J. 1982. Old Javanese-English dictionary (2 parts). KITLV publication. The Hague: Nijhoff. 


\section{University Library}

\section{- M M I E E R VA A gateway to Melbourne's research publications}

Minerva Access is the Institutional Repository of The University of Melbourne

Author/s:

Adelaar, A

Title:

Malagasy Phonological History and Bantu Influence

Date:

2012-06-01

Citation:

Adelaar, A. (2012). Malagasy Phonological History and Bantu Influence. OCEANIC LINGUISTICS, 51 (1), pp.123-159. https://doi.org/10.1353/ol.2012.0003.

Persistent Link:

http://hdl.handle.net/11343/121829 